\title{
Modelling THE EMERGING Pollutant Diclofenac With The GREAT-ER MODEL: APPLICATION TO THE LLOBREGAT RIVER BASIN
}

Joana Aldekoa

March 2013 
(C) Joana Aldekoa 2013

This is a degree project at the master's level done in association with the department of Land and Water Resources at the Royal Institute of Technology, Stockholm, Sweden, and in association with the Research Group of Hydrological and Environmental Modelling at the Polytechnic University of Valencia, Spain.

Department of Land and Water Resources Engineering

Royal Institute of Technology (KTH)

SE-100 44 STOCKHOLM, Sweden

Reference should be written as: Aldekoa, J. (2013) "Modelling the emerging pollutant diclofenac with the GREAT-ER model: application to the Llobregat River Basin" TRITALWR Degree Project 13:08 


\section{SUMMARY IN ENGLISH}

This Master Thesis, firstly, gives a general overview of occurrence of emerging pollutants in river water. A deeper study has been made for the emerging contaminant diclofenac and its behaviour, from consumption to natural degradation and effects. In order to predict the fate of diclofenac in a real catchment area main characteristics of Llobregat River Basin in Spain have been described.

Data gathering, about the pharmaceutical diclofenac and hydrologic aspects of the catchment, were one of the most laborious works, as it is explained along the thesis.

GREAT-ER has been the chosen model to simulate diclofenac occurrence in Llobregat River. Since its use is very limited worldwide, a full explanation about GREAT-ER geo-referenced aquatic exposure assessment model is included in this report: program methodology, main concepts, input files and simulation approach.

Simulation approach involved defining different scenarios and a calibration process which is specified in this paper. The results of this process and the derivate discussion mainly conclude in the future possible viability of the model.

This Master Thesis is addressed to researchers involved in water risk assessment as well as to people who work with water modelling systems. However, it is also intended to reach people interested in learning about emerging contaminants, its effects and a methodology to combat them: modelling. 


\section{SUMMARY IN SWEDISH}

Detta examensarbete ger först en generell översikt av gifter i vattendrag som ökar i förekomst. En djupare undersökning är gjord för den ökande föroreningen diclofenac, och dess påverkan från konsumtion till nedbrytning i naturen. För att förutse vägen för diclofenac $\mathrm{i}$ ett verkligt upptagningsområde har huvudegenskaperna från upptagningsområdet Llobregat i Spanien beskrivits.

Informationsinsamling av läkemedels-diclofenac och hydrologiska data från upptagningsområdet har varit bland de mer arbetskärvande uppgifterna, vilket förklaras i arbetet.

GREAT-ER har används som modell för att simulera förekomsten av diclofenac i vattnet i Llobregat-floden. Eftersom modellens användning är mycket begränsad världen över finns en fullständig beskrivning av GREAT-ER georefereras vattenlevande exponeringsbedömning modell i rapporten, med huvudbegrepp, in-filer och simuleringsmetod.

Simuleringsmetoden berör fastställande av olika scenarion och kalibreringsprocessen som användes $\mathrm{i}$ arbetet. Resultaten av denna process och följande diskussion fastställer främst framtida möjligheter för modellen.

Detta examensarbete är riktat till forskare inom riskbedömning för vattenflöden och personer som arbetar inom modellering av vattensystem. Det är även tänkt att nå personer intresserade av att lära sig om dessa gifter som ökar i förekomst, med dess påverkan och metoder för att bekämpa dem. 


\section{SUMMARY IN SPANISH}

Este Proyecto Final de Carrera, en primer lugar, ofrece una visión general de los contaminantes emergentes en aguas de ríos y el conflicto que supone. Además, se profundiza en el conocimiento del comportamiento del contaminante diclofenaco, desde su consumo a través del fármaco Voltaren, hasta su degradación natural y sus efectos en el medio ambiente. Es objeto de este PFC estudiar la presencia de esta substancia química en la cuenca del Llobregat, situada en el noroeste de España.

El trabajo de investigación sobre el diclofenaco y sobre las características hidrológicas de la cuenca ha resultado ser una de las tareas más complicadas, debido a su escasez y falta de fiabilidad.

GREAT-ER ha sido el modelo elegido para simular la presencia del diclofenaco en la cuenca del Llobregat. El uso de este geo-referenciado programa de evaluación de riesgo en ríos, no es conocido de forma global. Por este motivo, se ha procedido con un estudio profundo del funcionamiento del programa, con el objetivo de conocer su generación de archivos de entrada y los principios de simulación entre otros.

El proceso de simulación implica la consideración de diferentes escenarios y la calibración de parámetros, lo que dará lugar a ciertos resultados que se incluyen en el presente informe. Todo ello contribuye a la evaluación del modelo como posible herramienta para predecir concentraciones de contaminantes emergentes a escala de cuenca.

El PFC está dirigido a investigadores involucrados en el campo de calidad de aguas y gestión de recursos hídricos, así como a personas que trabajen con diversos modelos de sistemas de agua. Del mismo modo, este proyecto se quiere hacer llegar a todo aquél interesado en aprender acerca de los contaminantes emergentes, su comportamiento y efectos en el medio ambiente, y la metodología para hacerles frente. 


\section{ACKNOWLEDGEMENTS}

I would like to kindly thank my supervisor, Vladimir Cvetkovic, Department of Land and Water Resources Engineering, for all the advice given during the entire period of this Master's Thesis.

I would like to express my sincere gratitude to my supervisors at the Polytechnic University of Valencia (Spain), Chiara Medici and Félix Francés, who supported and guided me even when I was working in Sweden. They offered me their help for any technical aspect or language writing issue.

Another person to whom I would also like to extend my gratitude is Victoria Osorio, who provided the sampling data of the field campaigns in the Llobregat Catchment. Without this information the model could not be calibrated and, consequently, the obtained results would not have the same value and reliability.

Finally, I would love to thank Johan Dahlqvist for his help with the Swedish Summary, which he provided immediately. 


\section{TABLE OF CONTENTS}

Summary In English

iii

Summary In Swedish

Summary In Spanish

vii

Acknowledgements

ix

Table of Contents

Abstract

1. Introduction

2. Methods

2.1. Study Area

2.2. Data Collection

2.3. Emerging Contaminant Diclofenac

2.3.1. Consumption

2.3.2. Excretion patterns

2.3.3. WWTP removal efficiency

2.3.4. Biodegradation and sorption in rivers

2.3.5. Biodegradation and sorption in soils

2.3.6. Environmental effects

2.4. GREAT-ER Model

2.4.1. Methodology and model concepts 9

$\begin{array}{lll}\text { 2.4.2. Inputs } & 10\end{array}$

$\begin{array}{ll}\text { 2.4.3. Stochastic model } & 11\end{array}$

2.4.4. Scenarios 12

2.4.5. Calibration 13

3. Results 13

$\begin{array}{ll}\text { 3.1. Calibrated Parameters } & 18\end{array}$

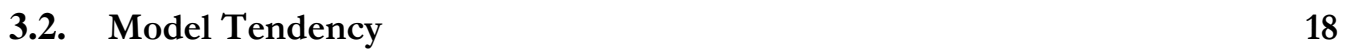

4. Discussion 18

4.1. Uncontrolled Discharges 19

4.2. Deterministic or Stochastic Approach 19

4.3. Calibrated Parameters 19

4.4. Lake Model 20

5. Conclusion 21

References 22

Appendix I - Results: concentration tables, RMSE, Csim/Cmeas factor,
emission, K (For each scenario's best result)

Appendix II - Consumption: data and estimations IV

Appendix III - Lake model: HRT estimation VII

Appendix IV - Velocity formula IX

Appendix V-Stretches, flow and velocity distribution in the Llobregat
Catchment 


\begin{abstract}
Water from the Llobregat is used to supply a significant part of the city of Barcelona. At the same time, 60 wastewater treatment plants discharge into this basin. Two field campaigns conducted in the Llobregat Catchment detected more than 80 pharmaceuticals in the water. Therefore, it is clear that water quality in Llobregat is a potential concern. A GIS hydrology water quality model has been applied in order to predict the concentrations of one of the pharmaceuticals, diclofenac, in the catchment. Consumption, excretion, and degradation data has been studied to calibrate the model. This exercise proves that it is relatively straightforward to predict the concentrations of new and emerging contaminants at basin scale. Nonetheless, the limited and inaccurate available data was a relevant obstacle in this modelling process.
\end{abstract}

Key words: Diclofenac; Llobregat; Predicted concentrations; GREAT-ER; Emerging Contaminants degradation

\title{
1. INTRODUCTION
}

Fresh-water pollution due to so-called Emerging Contaminants (ECs) started to receive attention only quite recently. In fact, this kind of contamination was not studied until around 1990; and was not recognized as a significant source of uncontrolled pollution. Nevertheless, the ECs may have a considerable negative impact on the environment and human health. ECs are used every day in our homes, on farms and in industry, and in products such as detergents, fragrances, prescription and nonprescription drugs, disinfectants and pesticides. After human activity and consumption they finally reach the environment through sewage water, by way of excretion or deliberate disposal.

Since these new contaminants have been studied just for the last two decades, the information about these compounds is very limited and uncertain. Therefore, it is fundamental to localize and control areas with potential environmental risk. To this end, mathematical modelling of a catchment area represents a useful tool to help supervising spatial and temporal distribution of ECs. The modelling approach aims to predict chemical concentrations in rivers, in particular during future events, and to obtain further knowledge of their behaviour.

The purpose of this work is to implement the model GREAT-ER for the Llobregat River Catchment, which is affected by large human activity, in order to study the effect and behaviour of the emerging contaminant diclofenac. Diclofenac is a commonly used non-steroidal antiinflammatory drug and is part of the EC group called Pharmaceuticals and Personal Care Products.

A literature review does not suggest too many models to predict the fate of emerging pollutants. Buser et al. (1988) used the GCSOLAR program from the U.S. EPA, which computes direct photolysis rates and half-lives of pollutants in the aquatic environment, in order to predict the occurrence of the diclofenac drug. However, more modelling studies have been found that utilised the geo-referenced environmental risk assessment tool GREAT-ER (Whelan et al, 1999; Schowanek and Webb 2000; Johnson et al, 2007; Ort et al, 2009; Alder et al, 2010).

According to different authors GREAT-ER is a simple model but is able to provide valuable information for aquatic exposure assessment (Alder et al, 2010) and is able to explore the potential influence of river discharge, flow velocity, source variability and in-stream decay rate on river water quality (Whelan et al, 1999). Based on initial simulations, it can be 
observed that not all exposure scenarios can be captured with the GREAT-ER model (Schowanek and Webb 2000; Ort et al, 2009). Nonetheless, even more complex water quality programs, accounting for degradation processes in a detailed mechanistic way, are unlikely to provide better results due to the lack of detailed, geo-referenced input information on industry, illegal discharges or unknown high temporal variation of consumption in a particular catchment (Whelan et al, 1999; Ort et al, 2009). Thus, a better achievement of local catchment information, waste water treatment plants' practices, current diclofenac consumption and behaviour data would refine input data and surely improve model results (Schowanek and Webb 2000; Johnson et al, 2007).

\section{METHODS}

These sections aims to describe model determinants, that is, the study area which has been implemented in the model, the Llobregat River Basin, the substance which has been studied and simulated, diclofenac, and the model itself, GREAT-ER.

\subsection{Study Area}

The Llobregat Catchment is located in Catalonia (Spain), northeast of the Iberian Peninsula (Fig. 1). The catchment area covers approximately $5000 \mathrm{~km}^{2}$. The Llobregat River length is about $160 \mathrm{~km}$ and discharges into the Mediterranean Sea. Its hydrology is characterized by a highly variable flow, which is strongly influenced by seasonal rainfall. The mean annual bulk precipitation is $3330 \cdot 10^{6} \mathrm{~m}^{3}$ and it has an annual average bulk discharge of $693 \cdot 106 \mathrm{~m} 3$. Its watershed is densely populated, with more than 3 million inhabitants living therein. Together with its two main tributaries, the River Cardener and the River Anoia, the Llobregat is subjected to a heavy anthropogenic pressure (Osorio et al, 2012). More than half of the population is situated close to the coast, which is the lower area of the catchment.

Water from Llobregat is used to supply water to a significant part of the city of Barcelona. A mean value of $7.3 \cdot 10^{6} \mathrm{~m}^{3}$ per month of superficial water is demanded for Sant Joan Despí drinking water treatment plant (the biggest of Catalonia). At the same time, 60 wastewater treatment plants discharge in this basin. Therefore, water quality is a potential concern in this catchment.

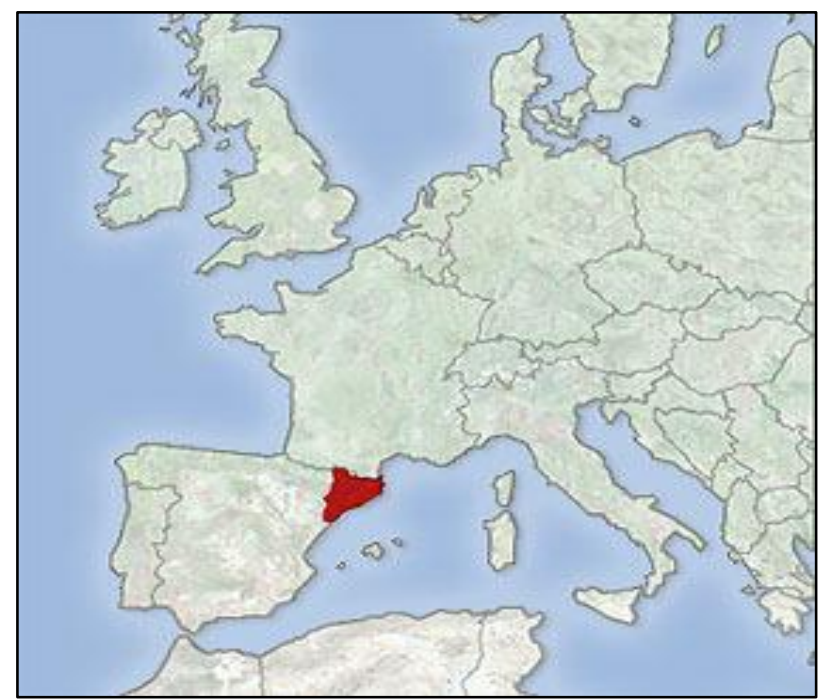

Figure 1. Location of Catalonia autonomous community. 


\subsection{Data Collection}

In order to model the Llobregat Catchment, different data was required.

Firstly, daily flow levels were gathered from 14 control points and entry and exit flows from the three reservoirs, in order to estimate hydrological variables. The source of this data comes from the Catalan Water Agency (ACA). It is important to note that 6 out of 14 control points stopped working from September 2010 to September 2011.

Secondly, data of waste water treatment plant discharges and water supplying extractions was collected, from the Hydraulic and Environmental Department at the Polytechnic University of Valencia, to determine the contaminant input and output amount and location.

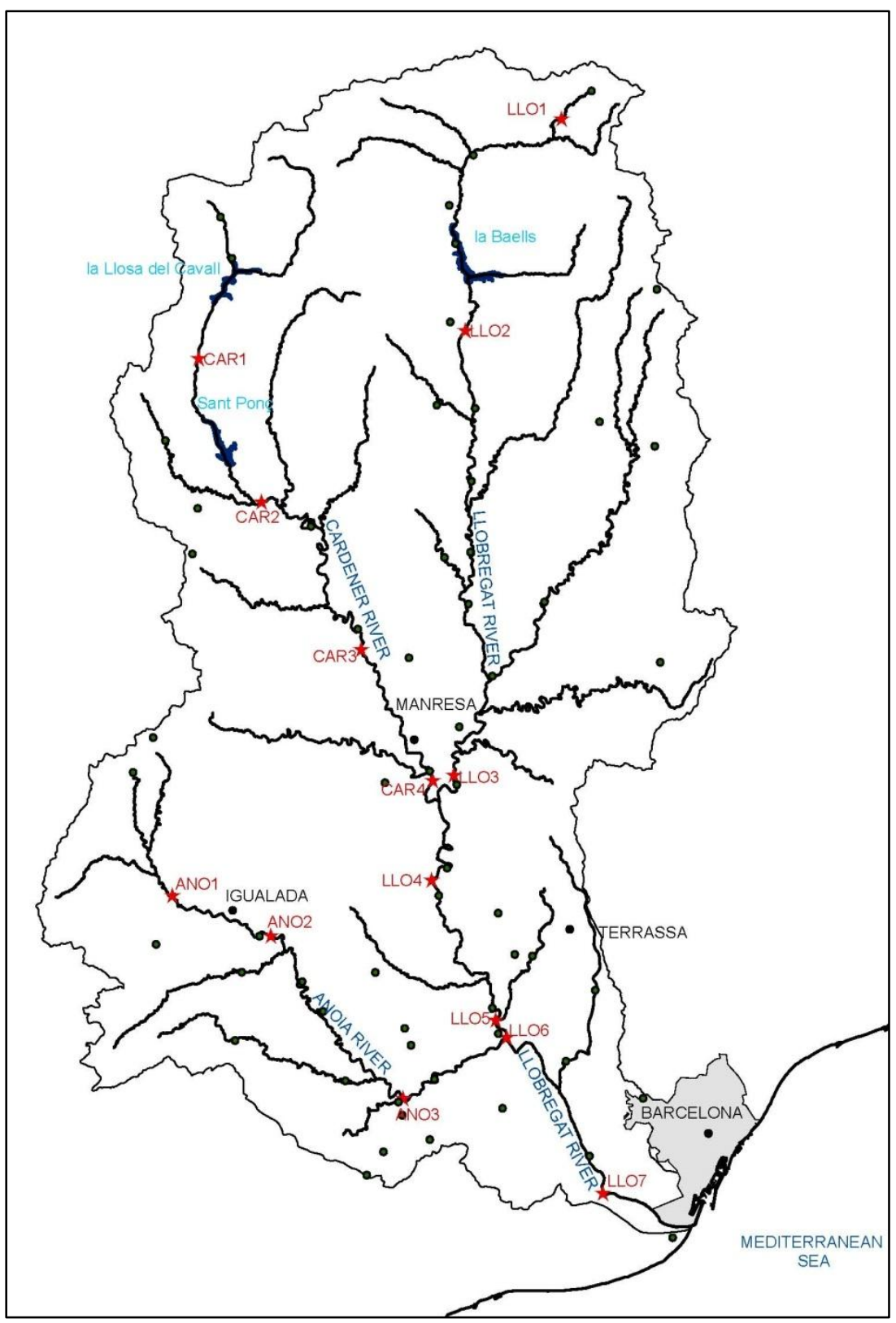

Figure 2. Llobregat Catchment area. Location of 14 sampling points (red stars) and WWTPs (green points). 
Finally, some field data is provided in order to validate the model. In the Llobregat River two field campaigns were conducted to detect several chemicals, on September 22, 2010 and September 13, 2011. In 14 points of the catchment (Fig. 2) diclofenac concentration was measured, among other pharmaceuticals. These two field campaigns were undertaken for the SCARCE international research project, with the objective to assess and predict the effects on water quantity and quality in Iberian rivers caused by global change.

\subsection{Emerging Contaminant Diclofenac}

Diclofenac (2-(2-(2,6-dichlorophenylamino)phenyl)acetic acid) is a widely used non-steroidal anti-inflammatory drug (NSAID). It is generally used as an analgesic to reduce pain and to treat inflammatory disorders, especially arthritis and rheumatism. Diclofenac is mostly available as sodium or potassium salt in the United Kingdom, India, Brazil, the United States and many other countries. In Spain it is mainly used in Voltaren medical products, such as sodium salt (Buser et al, 1998).

Data on diclofenac found in the literature about its biodegradation behaviour, effects in the natural environment and consumption patterns is quite varied and imprecise. Nonetheless, the following sections summarise the main properties of diclofenac utilised in this project.

\subsubsection{Consumption}

A few years ago the worldwide annual consumption of pharmaceuticals was $15 \mathrm{~g}$ per capita; in developed countries this amount was three to ten times higher, that is, 50-150 $\mathrm{g}$ ( $\mathrm{Pal}$ et al, 2010). Moreover, as a result of the increasing average age of the population and the tendency of the human genome, drug use is expected to grow (Jones et al, 2005) in the near future.

Diclofenac is one of these pharmaceuticals which is consumed worldwide. The human administration method varies between tablets, capsules, suppositories, intravenous solutions, and ointments and gels for dermal application (Buser et al, 1998). It is estimated that 940 tons of this anti-inflammatory drug are consumed annually all over the world (Al-Rajab et al, 2010).

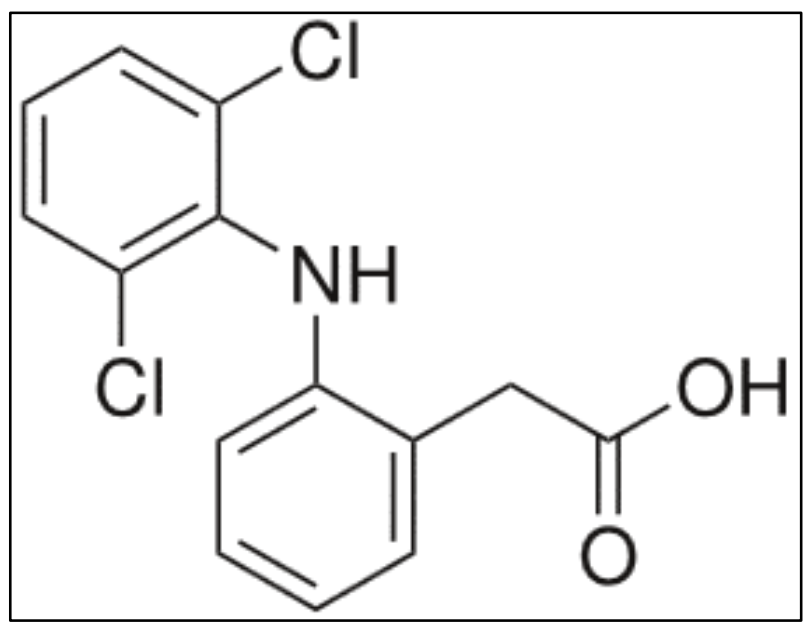

Figure 3. 2D structure of the NSAID-class drug diclofenac. 
Despite the estimations suggesting that diclofenac's impact on the environment are probably worth studying due to its significant consumption, very little data exists about diclofenac local consumption in Spain in order to estimate specific consumption in the area of interest for this project. The only published report from the Spanish Ministry of Health about non-steroidal anti-inflammatory drugs estimates the use of diclofenac in the whole country in 2006 (7.87 DDD/1000 inhab./day) (Spanish Agency of Medicaments and Sanitary Products, 2007).

\subsubsection{Excretion patterns}

After administration, diclofenac is excreted by humans and discharged into the sewage system, as with all pharmaceuticals and personal care products. This excretion occurs after the drugs are partially or completely metabolised by the human body. As a result, unchanged and conjugated compounds are released through urine and faeces (Carballa et al, 2008).

According to several studies, the elimination of $90 \%$ of diclofenac happens 3 or 4 hours after its consumption. Moreover, the pattern of metabolites and excretion is independent of the method of administration. Several conjugated forms derive from diclofenac, and the most significant one is 4-hydroxydiclofenac. $40-50 \%$ of the excreted dose from urine and bile comes in this conjugated form (Johnson et al, 2007). This means that just a fraction (probably under $50 \%$ ) of the consumed diclofenac arrives to the waste water treatment plants in its unchanged form. The model suggested in this work aims to predict the diclofenac parent compound; therefore, it will not foresee its conjugated forms. Different literature sources have been consulted to obtain an interval for diclofenac excretion rates values (Table 1). As a result, diclofenac excretion rates for its unchanged form vary between $1 \%$ and $39 \%$.

\subsubsection{WWTP removal efficiency}

The pharmaceuticals that are released from humans reach waste water treatment plants (WWTPs) through sewers. Biodegradation of most drugs takes place in these WWTPs before they arrive into the river. In addition, compounds transformation and degradation may also occur during in-pipe transportation to WWTPs. However, as conditions in sewers in terms of residence time, temperature, solids content and aeration are not favourable for biodegradation (Carballa et al, 2008), transport through sewers will not be considered as a relevant cause of elimination of diclofenac.

Once diclofenac is exposed to sewage plants' treatments, it will be affected by sorption, volatilization and degradation processes. Biodegradation will mainly develop in the secondary treatment stage, as a consequence of large concentrations of microorganisms. Nevertheless, due to the significant amounts of the $\beta$-glucuridase enzyme, it is probable that gluconoride and sulphate conjugates of drug compounds are deconjugated in some treatments (Jones et al, 2005).

The efficiency of WWTPs to eliminate drugs depends on physicochemical properties and on the specific treatments of each plant. Therefore, diclofenac's aqueous solubility, volatility, lipophilicity and other properties will affect this process (Carballa et al, 2008). Several studies and laboratory practices reveal that diclofenac's molecule is moderately biodegradable, but weakly sorptive (Johnson et al, 2007). 
Table 1. Diclofenac excretion rates, for its unchanged and conjugated form, from literature. n.d.: no data.

\begin{tabular}{|c|c|c|}
\hline Authors & Unchanged diclofenac & Conjugated \\
\hline M. Carballa et al., 2008 & $1-15 \%$ & $1-60 \%$ \\
\hline D. Bendz et al., 2005 & $15 \%$ & $<1 \%$ \\
\hline A. C. Johnson et al., 2007 & $7.50 \%$ & n.d. \\
\hline J. Lienert et al., 2007 & $6-26 \%$ & $45-85 \%$ \\
\hline H. T. Scheneider et al, 1990 & $12.66 \%$ & $22.07 \%$ \\
\hline T. L. Laak et al, 2010 & $6-26 \%$ & n.d. \\
\hline A. Pal et al., 2010 & $6-39 \%$ & n.d. \\
\hline
\end{tabular}

Treatment processes at WWTPs will have different influence on the degradation of drug compounds. For instance, biological treatments can provide the double removal percentage of diclofenac than a primary sedimentation tank. At the same time, the efficiency of activated sludge plants improves if nitrogen treatments are included. Some research studies also suggest that the removal increases with higher influent concentrations to the plant (Miege et al, 2009). According to other studies, a pilot ozonation, UV-disinfection and activated carbon treatments could remove a significant fraction (95\%) of diclofenac and other pharmaceuticals (Jones et al, 2005; Ort et al, 2009). On the other hand, biological filters may eliminate less than $9 \%$ (Johnson et al, 2007).

Due to the multiple factors that influence the degradation of diclofenac in WWTPs, literature values are rather variable. Despite the fact that most authors indicate poor removal efficiency in conventional sewage treatments, numeric values imply low and high rates. Different data collected from literature is gathered in table 2 .

Table 2. WWTP removal efficiency for diclofenac from literature.

\begin{tabular}{ll}
\hline Authors & Removal \% \\
\hline A. C. Johnson et al., 2007 & $0-75$ \\
J. Lienert et al., 2007 & $<6$ \\
D. Bendz et al., 2005 & $17-69$ \\
C. Miege et al., 2009 & 32 \\
T. Heberer, 2002 & 17 \\
C. Ort et al., 2009 & \\
\hline
\end{tabular}




\subsubsection{Biodegradation and sorption in tivers}

The available data for diclofenac's behaviour in river water is very variable. On the one hand, some authors suggest that diclofenac is affected by potential transformation processes and in consequence it will be mostly declined (Bendz et al, 2005); on the other hand, others define diclofenac as a conservative solute (Johnson et al, 2007).

In general, researchers agree on little sorption capacity for diclofenac, which at the same time implies a negligible adsorption onto lake sediments (Buser et al, 1998; Kunkel and Radke, 2011). Despite the fact that sorption capacity is a function of the sediment type, some models calculate a rate constant $\left(\right.$ day $\left.^{-1}\right)$ for sedimentation of 0.005 (Tixier et al, 2003; Jiskra, 2008).

In several studies, photodegradation and biodegradation have been found to be the main reason of diclofenac removal in environmental waters. Nevertheless, biodegradation is directly connected to sewage effluents. As a result, it mostly appears in waste water treatment plants. However, diclofenac's biodegradation has a quite variable response in river water (Jiskra, 2008). Some laboratory studies estimate a degradation constant of about 0.004-0.006 day-1 (Buser et al, 1998; Tixier et al, 2003); therefore, diclofenac degradation would only be appreciable in rivers with very long residence time (Johnson et al, 2007).

According to laboratory and incubation experiments and field studies, diclofenac has a clear tendency to be affected by photochemical degradation (Buser et al, 1998; Tixier et al, 2003; Kunkel and Radke, 2011). Nonetheless, this process has a different impact depending on the season of the year, geographic latitude, weather and depth into the water (Jiskra, 2008).

Buser et al. (1998) did a thorough study of diclofenac photodegradation capacity in lakes. The field study, where more than $90 \%$ of diclofenac was degraded in the lake, suggested an elimination rate between 0.022 and 0.081 day- $^{-1}$, for winter and summer, respectively. A modelling calculation was also made, where photodegradation rates varied from 0.006 to 0.14 day- $^{-1}$, with an annual average of 0.068 day- $^{-1}$ (Buser et al, 1998). Other research studies estimated a phototransformation rate of about 0.082 day- $^{-1}$ (Tixier et al, 2003). As mentioned, the depth considered can affect elimination values. In some experiments $97 \%$ decomposition was detected at $50 \mathrm{~cm}$ depth, whereas the decomposition at $1 \mathrm{~m}$ depth was just 30\% (Jiskra, 2008).

Table 3. K degradation constant (day $\left.{ }^{-1}\right)$ for diclofenac. Minimum value, maximum value and average, on every process.

\begin{tabular}{lccr}
\hline $\mathrm{K}\left(\mathrm{d}^{-1}\right)$ & Min. Value & Max. Value & Average \\
\hline Photodegradation & 0.006 & 0.14 & 0.068 \\
Biodegradation & 0.004 & 0.01 & 0.006 \\
Sedimentation & 0.005 & 0.005 & 0.005 \\
Overall & & & 0.079 \\
\hline
\end{tabular}


Despite photodegradation being a relevant process in lakes, its effects in rivers are harder to appreciate. As a result of a tracer test done in a river, diclofenac was not attenuated (Kunkel and Radke, 2011). The lack of this photolysis effectiveness could be attributed to the high turbidity of the river water, to the low exposure to sunlight, to the cloudy weather during the experiment and to the low residence time of the drug in the river. Therefore, photodegradation is the most important process which affects diclofenac; however, its effectiveness will vary in every situation and can diminish enough to get no response in rivers.

Taking into account all data found in literature, table 3 shows the value intervals considered in this work to represent the degradation rate of diclofenac in environmental water.

\subsubsection{Biodegradation and sorption in soils}

The degradation of diclofenac has mostly been studied in river water. However, water is also taken from rivers to irrigate lands. As a consequence, some research studies of diclofenac degradation in soils have also been carried out.

Soil laboratory studies have concluded that with high temperatures, the presence of microorganisms, aerobic conditions and unsaturated water conditions, the degradation rate for diclofenac is between 0.0234 and $0.2236 \mathrm{~d}^{-1}$ (Al-Rajab et al, 2010; Lin and Gan, 2011). These are relatively high values considering the estimated rates for diclofenac degradation in river water. In addition, generally most irrigation water becomes groundwater.

These assumptions suggest that very little diclofenac will return to river water. Therefore, there is no relevant need to consider a new disperse source of diclofenec in the model provided in this work.

\subsubsection{Environmental effects}

Pharmaceuticals, after transportation through the sewage system and natural water, interact with environment biota. This interaction may vary for every drug compound and for every environmental condition. Several studies have been carried out to determinate some of the effects caused by the pharmaceuticals and personal care products in the natural environment.

According to some authors, non-polar compounds can be accumulated in fish and other aquatic biota, in sediments or in sewage sludge (Heberer, 2002). The most susceptible species to pharmaceuticals in water seems to be daphnids and water fleas, followed by fish and algae. Sex hormones might provoke adverse impacts, such as feminization (Lin and Gan, 2011); therefore, great concern is focused on estrogen and androgen hormones ( $\mathrm{Pal}$ et al, 2010). However, many pharmaceuticals also generate a potential concern, as a consequence of their emerging impact on nature.

Different environmental impacts of the diclofenac drug have been found through research studies in the last decade. Diclofenac causes some toxicity to birds and alterations in the composition of river biofilm communities (Al-Rajab et al, 2010), as well as sub-lethal effects on daphnids and fish embryos (Scheneider et al, 1990). This drug compound seems to appear potentially phytotoxic only in concentrations that are not occurring in nature; however, its photodegradation products may present five to six times higher toxicity (Jiskra, 2008). In addition, it is not a less relevant fact that water is collected from rivers to supply drinking water for humans, while at the same time this water might contain diclofenac, among other pharmaceuticals. Some years ago diclofenac was identified (under 
$10 \mathrm{ng} / \mathrm{l}$ ) in a private drinking water tap in Berlin-Zehlendorf (Heberer, 2002). Hence, diclofenac consumption could also affect human health.

\subsection{GREAT-ER Model}

The GREAT-ER (Geo-referenced Regional Exposure Assessment Tool for European Rivers) system is an aquatic exposure prediction tool for 'down-the-drain' chemicals within environmental risk assessment schemes (Boeije et al, 1997; Schowanek and Webb 2000). It was developed and validated by ECETOC (European Centre for Ecotoxicology and Toxicology of Chemicals) (Schowanek and Webb 2000) in 1997.

The GREAT-ER model structure is deterministic and stationary. However, variability and parameter uncertainty can be considered applying the Monte Carlo approach.

Several studies have been undertaken with this model worldwide (e.g.: UK, Switzerland, Germany, Turkey, China and Australia). Even if its use is not widespread in Spain, a few studies have already been made with the GREAT-ER model in the Llobregat Basin.

\subsubsection{Methodology and model concepts}

The GREAT-ER structure is basically composed of discharge points and river stretches (Fig. 3).

Discharges represent waste water treatment plants, which are the input of chemical contaminants into the river network. Through these points the contaminant flux is introduced as mass per time.

Every river stretch is modelled by its start and end point (according to water current direction). The start point receives the chemical flux of the upstream stretch or stretches and the discharge mass of a WWTP if it exists. Between the start and end point of the stretch a decay model is applied, by a first-order in-stream removal and in accordance with the defined substance properties. Through this method the output of the stretch is calculated, which is the input for the next downstream stretch. As a result, the chemical mass is transported through river stretches down to the drainage point of the basin.

The GREAT-ER model provides three simulation modes depending on the level of complexity required. This way, more specific processes can be simulated in WWTPs and rivers, involving substance degradation. In this project, the first mode has been used for the modelling of the Llobregat Catchment, due to the lack of available data needed in higher complexity modes.

First-mode simulates the removal efficiency of waste-water treatments applying an overall removal rate. Degradation in rivers is calculated with the following equation in every river stretch:

$$
\mathrm{R}_{\text {river }}=1-\mathrm{e}^{-\mathrm{HRT} T^{*} \mathrm{~K}}
$$

Where $R_{\text {river }}$ is the removal rate corresponding to the specific stretch, $K$ is the degradation constant of the chemical contaminant $\left(\mathrm{h}^{-1}\right)$, and HRT is the travel time in the stretch (h) calculated as HRT=L/v/3600, with length $(\mathrm{m})$ and velocity $(\mathrm{m} / \mathrm{s})$.

GREAT-ER can also model lakes with the same first-order removal, but travel time is calculated as HRT $=\mathrm{V} / \mathrm{Q} / 3600$, with volume $\left(\mathrm{m}^{3}\right)$ and water flow $\left(\mathrm{m}^{3} / \mathrm{s}\right)$. 


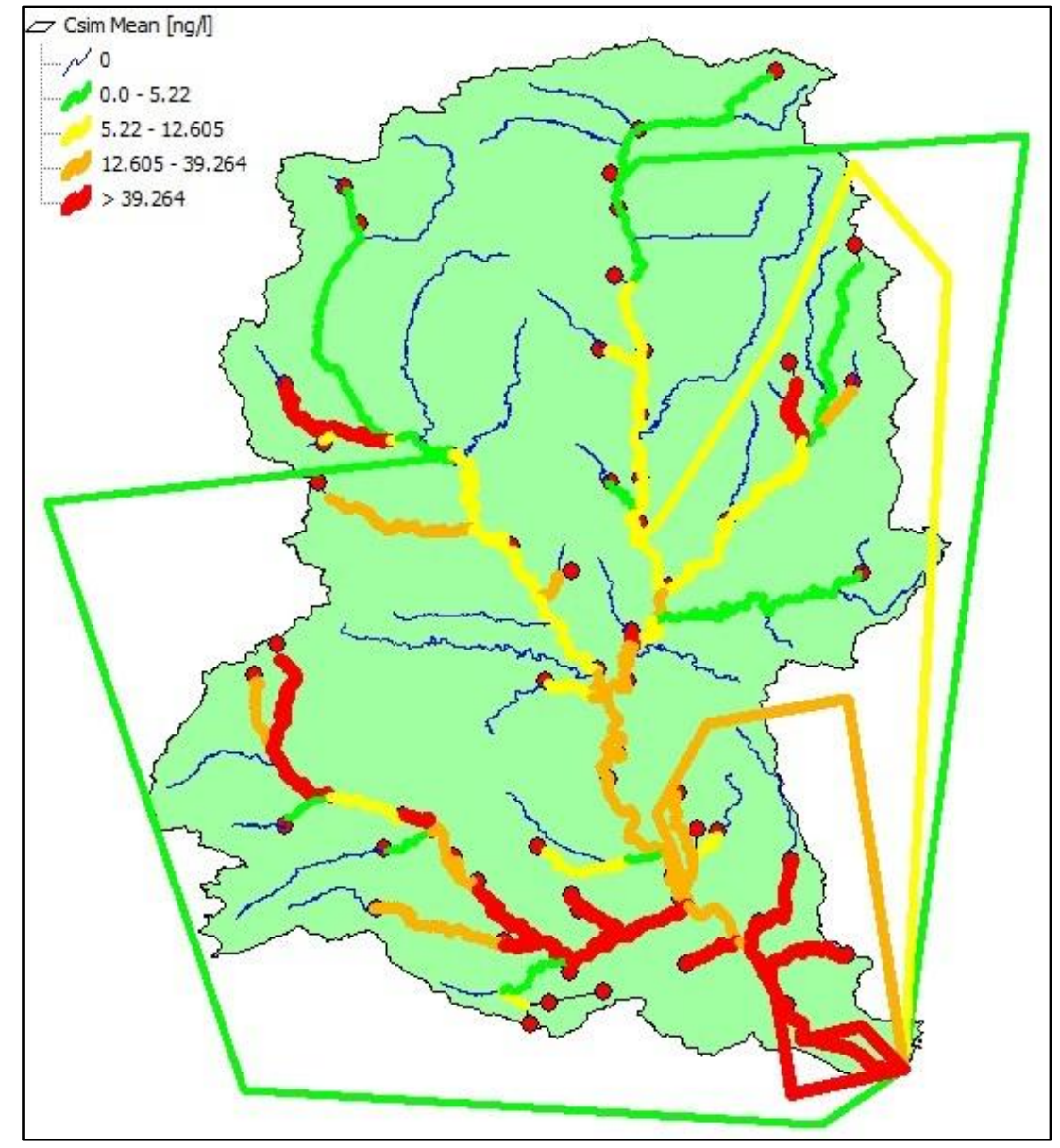

Figure 4. GREAT-ER model layout for the Llobregat Catchment. Red points represent discharge points: WWTPs. Different colours at river stretches indicate concentration levels.

Once the mass per time charge has been simulated through the entire river network, GREAT-ER calculates concentrations with the water flow of each stretch. Consequently, the model gives the final result of the concentrations in the start and end points of every stretch. Figure 4 shows the layout of the GREAT-ER model with the resulting concentrations through the entire river network.

GREAT-ER models the input of chemical mass to river water. Nevertheless, the reductions of chemical mass from the river due to extractions of supplying water (drinking or irrigation water) are not modelled. Therefore, with the aim of simulating extractions for main water demands in the catchment, new river stretches were introduced at the extraction points. These artificial stretches can be identified outside the catchment (Fig. 3). This method allows representing the loss of chemical mass in these artificial bifurcation points.

\subsubsection{Inputs}

The GREAT-ER model requires seven input (text) files.

\section{Digital River Network.}

The entire river network is divided into stretches, taking into account bifurcations, confluences, discharge points and sampling points. Each stretch is identified by a number, ordered according to water current. 
This file contains the geographic coordinates of the points that determine the river network, gathered into stretches by their identification numbers. The spatial points in this file will generate the spatial distribution of the river in the model.

\section{River Network. Attributes}

Properties of every river stretch are defined within this file: stretch identification, flow mean value, flow $5^{\text {th }}$ percentile, velocity mean value, velocity $5^{\text {th }}$ percentile, length, depth mean value, depth $5^{\text {th }}$ percentile and name.

\section{Discharge Site Data}

Contaminants discharges are defined in this file. The discharges emanate from waste-water treatment plants. Identification, geographic coordinates, population, discharge flow, treatment type, discharged river stretch and names are stated.

\section{Catchment Boundary Polygon}

Geographic coordinates of the catchment boundary points (a polygon) are given.

$$
\text { Lakes }
$$

The stretches which are lakes are identified in this file.

\section{Pictures}

Pictures of the catchment can be included in this file.

$$
\text { Background }
$$

This file provides access to geographic background information.

Several tools have been used to model the Llobregat Catchment and generate its input files. ArcGIS has been an essential program to work with geographically referenced data. Using ArcGIS catchment boundary points, and river network stretches division, identification and points have been generated, along with other spatial calculations. Matlab was also required to provide a function able to order the 160 stretches of the river network, obtain the required format and other details which the model demands. Excel's macros have also been used to calculate geographic coordinates (from UTM coordinates) of more than 20.000 points.

\subsubsection{Stochastic model}

GREAT-ER is defined as a deterministic model with a stochastic approach (Monte Carlo method) on top of it. Stochastic simulations permit one to take into account seasonality of environmental factors and parameter uncertainty. Seasonality deals with environmental variations throughout the years for water flow or velocity factors. Parameter uncertainty deals with the difficulties to estimate model parameters, such as WWTP removal efficiency or consumption of chemical contaminants (Boeije et al, 1997).

The GREAT-ER model requires introducing the mean value and $5^{\text {th }}$ percentile of water flows and other hydrologic variables, as well as certain model parameters distribution. The Monte Carlo method generates randomly discrete 'shots' from these input distributions. For each 'shot' the previously described deterministic method (2.3.1) is applied. Therefore, the model generates many concentration results as Monte Carlo outcomes. GREAT-ER defines a log-normal distribution for these concentrations in each stretch and provides as a result its mean and standard deviation value. 


\subsubsection{Scenarios}

Due to the existence of two field sampling campaigns and the option to apply a deterministic or stochastic model four different scenarios have been suggested.

Scenario 1

Deterministic model for first campaign (flow, velocity and consumption data of September 2010).

Scenario 2

Deterministic model for second campaign (flow, velocity and consumption data of September 2011).

Scenario 3

Stochastic model for first campaign (flow and velocity mean and percentile values from 2000 to 2012, and consumption data of September 2010).

\section{Scenario 4}

Stochastic model for second campaign (flow and velocity mean and percentile values from 2000 to 2012, and consumption data of September 2011).

\subsubsection{Flow and velocity calculation}

Water flow and velocity in the river are the two main hydrological variables which the GREAT-ER model uses for the simulation and are required in the input files. Therefore, flow and velocity were estimated for every river stretch and in each scenario.

Our first aim was to represent the real or altered water flow for the days that the samples were taken (September 22, 2010 and September 13, 2011) for the deterministic models.

The available data to estimate flows were 14 river control points all over the catchment (where the flow level is measured daily) and entry and exit flows of reservoirs. Temporal data of water discharges and demands was also available. Therefore, taking into account measured levels, discharged and extracted flows from the river and the natural water contribution (by constant flow/drained area rates) flow values were estimated for every river stretch through a water balance.

Our second objective was to construct data for a stochastic model. Therefore, mean values and $5^{\text {th }}$ percentile values were calculated for most variables (flows in control points, discharges and extractions). Afterwards, the same method as in the deterministic model was applied to estimate the flows (mean values and $5^{\text {th }}$ percentile) in every stretch.

For velocity (v) calculation, an expression function of flow (Q), slope $\left(\mathrm{S}_{0}\right)$ and drained area $(\Lambda)$ was suggested (Appendix IV).

$$
v=F C \cdot\left[\frac{Q^{(2 / 3-\xi \theta)\left(1-\varepsilon_{2}\right)} \cdot S_{0}^{(1 / 2-\xi \theta)}}{c_{n} \cdot c_{d}^{\xi} \cdot\left(c_{1} \cdot \kappa^{\left(\varepsilon_{1}-\varepsilon_{2}\right)} \cdot \Lambda^{\varphi\left(\varepsilon_{1}-\varepsilon_{2}\right)}\right)^{(2 / 3-\xi \theta)}}\right]^{\frac{1}{1+2 / 3-\xi \theta}}
$$

This expression derives from the Manning formula and integrates several parameters $(\xi, \theta, \varepsilon, \varphi, \mathrm{c}$, and $\kappa)$ according to geomorphologic relations and the hydraulic geometry of the river network. Parameters were obtained for the Llobregat River and the correcting factor FC was calibrated with data provided by the HEC-RAS model. 
The ArgGIS tool was used to create raster layers for flow values, slope and drained area. As a result, a new layer of velocity was generated, which is a function of the previous expression. This process allowed estimating a velocity value for every stretch.

Appendix IV shows the distribution and identification of the stretches, as well as the resulting water flow and velocity value for each stretch.

\subsubsection{Calibration}

The purpose of the calibration work was to adjust the model according to the measurements of field campaigns in order to make it valid. Hence, once the Llobregat Catchment was implemented some specific parameters were corrected through a calibration process.

The parameters of the model are: diclofenac degradation constant in nature $(\mathrm{K})$, removal efficiency of waste water treatment plants, excretion rate by humans and diclofenac drug consumption in the affected area. Nevertheless, all these parameters, except the natural degradation constant, have been considered as one: diclofenac emission. WWTP removal and excretion rates are percentages that are applied to the consumption data straight away. As a result, an emission from WWTPs of mg per time is modelled.

In conclusion, the aim of this calibration work was to adjust the values of two parameters: $\mathrm{K}$ (natural degradation constant) and diclofenac net emission. Resulting concentrations from the model were compared to the concentrations measured during the two field campaigns in 14 points of the Llobregat River.

The methodology for adjusting the model is the primitive method of trial and error. The error was measured by the Root Mean Square Error (RMSE). Thus, the goal was to minimise the RMSE with K degradation constant and diclofenac emission.

\section{RESUlts}

The GREAT-ER model has been used to predict the fate of the diclofenac drug in the Llobregat River. For this purpose, information on diclofenac behaviour has been gathered, followed by the introduction of the Llobregat Catchment into the model and a final calibration.

The GREAT-ER model provided the following results for each scenario (Fig. 4) with their corresponding RMSE (Table 4).

Appendix I summarises numerical data from the results and the error criterion. 


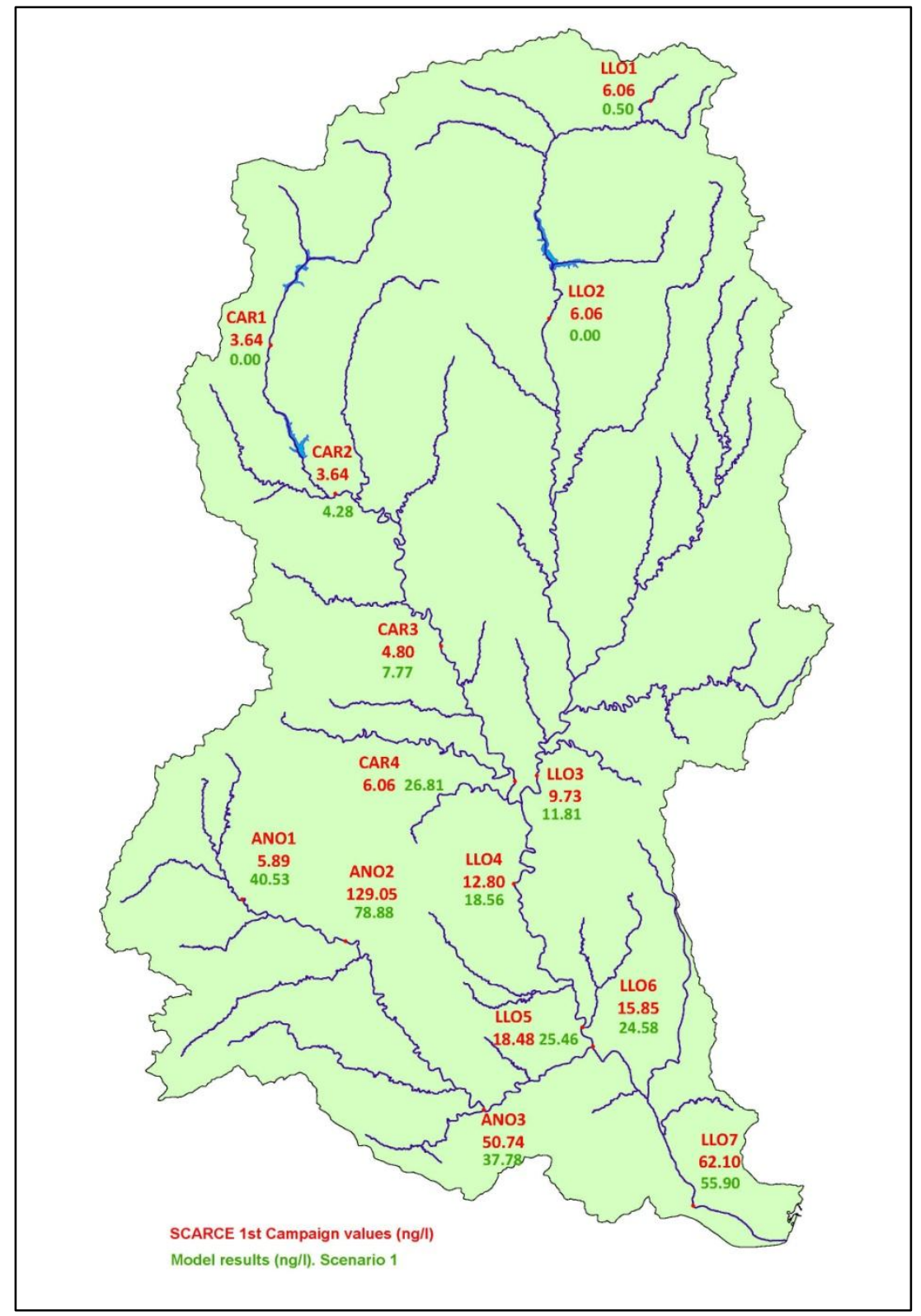

Figure 5. Measured concentrations (ng/l) at field campaigns (red colour) and resulting concentrations (ng/l) from the GREAT-ER model with scenario 1 (September 2010, deterministic approach), average value and standard deviation value (green colour), in the 14 sampling points. 


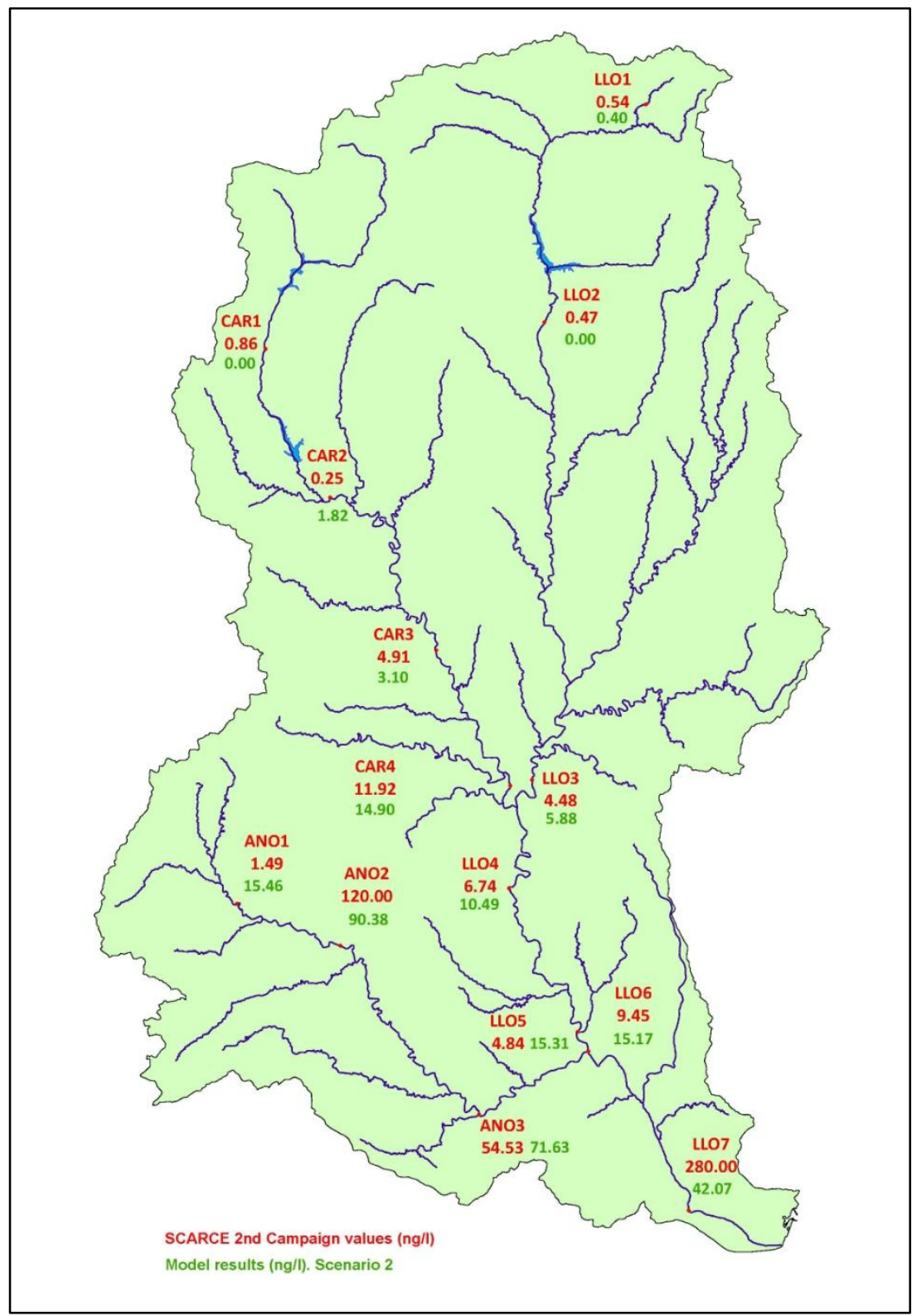

Figure 6. Measured concentrations (ng/l) at field campaigns (red colour) and resulting concentrations (ng/l) from the GREAT-ER model with scenario 2 (September 2011, deterministic approach), average value and standard deviation value (green colour), in the 14 sampling points. 


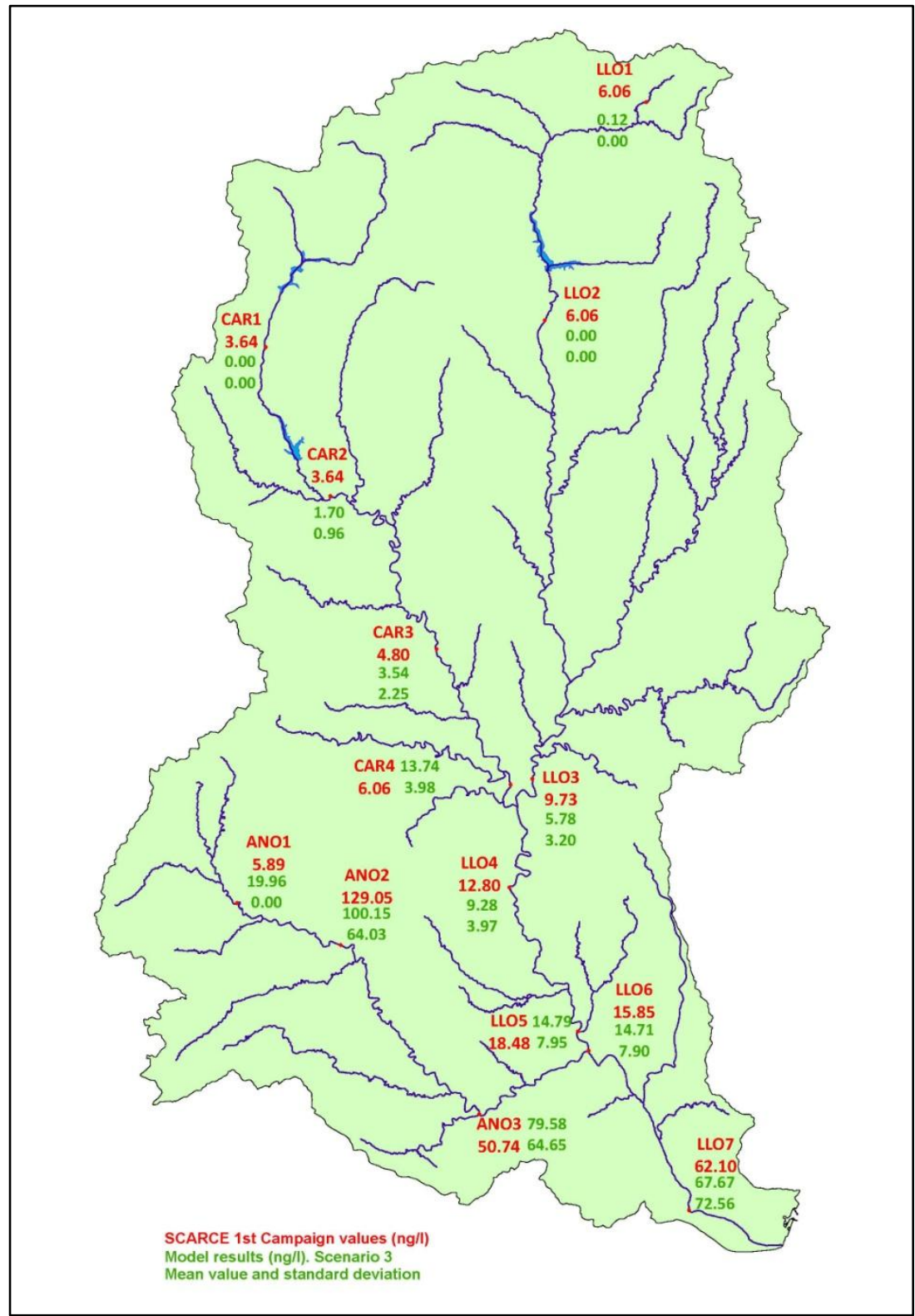

Figure 7. Measured concentrations (ng/l) at field campaigns (red colour) and resulting concentrations (ng/l) from the GREAT-ER model with scenario 3 (September 2010, stochastic approach), average value and standard deviation value (green colour), in the 14 sampling points. 


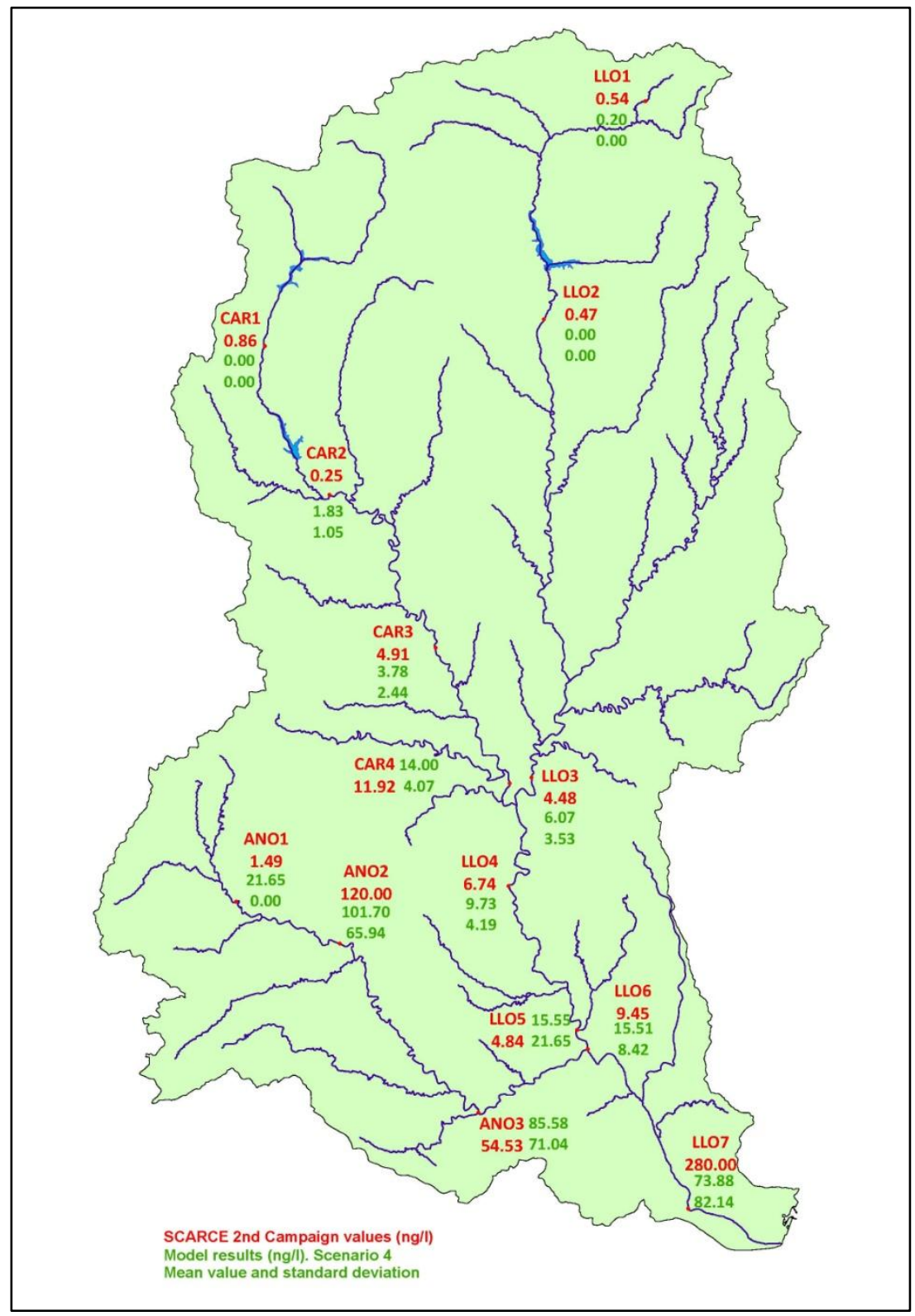

Figure 8. Measured concentrations (ng/l) at field campaigns (red colour) and resulting concentrations (ng/l) from the GREAT-ER model with scenario 4 (September 2011, stochastic approach), average value and standard deviation value (green colour), in the 14 sampling points.

Table 4. Root Mean Square Error (ng/l) for each scenario.

\begin{tabular}{lrrrr}
\hline SCENARIO & $\mathbf{1}$ & $\mathbf{2}$ & $\mathbf{3}$ & $\mathbf{4}$ \\
RMSE & 18.1 & 64.4 & 12.2 & 56.3 \\
\hline
\end{tabular}

Table 5. GREAT-ER model estimation for diclofenac emission (g/cap/year) out of WWTPs.

\begin{tabular}{lrrrr}
\hline SCENARIO & $\mathbf{1}$ & $\mathbf{2}$ & $\mathbf{3}$ & $\mathbf{4}$ \\
Diclofenac & & & & \\
Emission & 0.0506 & 0.0129 & 0.0115 & 0.0115 \\
\hline
\end{tabular}




\subsection{Calibrated Parameters}

Through the calibration process it has been possible to prove that contaminant emission is a much more significant parameter than the natural degradation constant. Calculated concentrations can be two or even three times higher depending on the adopted WW'TP removal efficiency or excretion rate. The estimated diclofenac emission out of WWTPs for each scenario is provided in table 5. Assuming that in 2010 and 2011 the diclofenac drug consumption was similar to the consumption published for 2006 (0.787 mg/cap/day (Spanish Agency of Medicaments and Sanitary Products, 2007), excretion rates and WWTP removals have been approximately estimated from the emission results. The resulting values imply a large reduction of emission from its consumption. This means that excretion rates are low (10-20\%) and WWTP removal efficiency high $(50-70 \%)$.

The degradation constant also implies significant changes in concentration values, especially with low water velocity which implies a higher residence time available for degradation, but its effect is always less noticeable. However, after comparing the error for the high degradation constant $\left(0.155 \mathrm{~d}^{-1}\right)$ and low constant $\left(0.015 \mathrm{~d}^{-1}\right)$, it was concluded that concentrations are more properly estimated with high biodegradability for diclofenac. Despite the fact that different $\mathrm{K}$ values did not yield high RMSE differences, $0.15 \mathrm{~d}^{-1}$ appeared to be the most adequate rate in the four scenarios.

\subsection{Model Tendency}

The GREAT-ER model was able to predict diclofenac concentrations in the Llobregat River network with a certain margin of error. GREAT-ER agreed with $2^{\text {nd }}$ campaign samples (September 2011) taken in the upper part of the catchment, which are the lowest. Nonetheless, GREAT-ER estimated even a lower concentration for points which were downstream of the lakes. The model tends to apply a complete degradation in lakes, whereas field samples can still detect concentrations over $0.1 \mathrm{ng} / \mathrm{l}$.

The concentrations did not match with $1^{\text {st }}$ campaign samples (September 2010) taken in the upper part of the catchment (LLO1, LLO2 and CAR1). However, these sampling values are repeated exactly in other sampling points (CAR2 and CAR4), which can be considered inconsistent. Unfortunately, there has not been a chance to assure the reliability of this data.

The model followed the tendency of diclofenac through the Llobregat River and Cardener Tributary River, with generally acceptable over- or under- estimations. The model overestimated concentration in the highest point of the Anoia River, but underestimated the middle point. A possible reason could be the low flows and high variability that characterises this affluent, which complicates the estimations of flows in the river. A similar problem exists in the last sampling point (LLO7). The flow variability and uncertainty is the highest close to the discharge point of the river. Field campaigns show high concentrations, which GREATER did not calculate properly. However, the model predicted the increase of concentration in this downstream point (LLO7).

\section{Discussion}

The GREAT-ER model is able to estimate diclofenac concentrations all over the Llobregat Catchment, according to some hydrological variables (flow and velocity) as well as substance degradation properties and consumption rates. Despite the fact that calculated concentrations do not match exactly sampling data, the model captures the tendency of 
diclofenac occurrence. It is able to predict where concentrations increase or decrease considerably, following the diclofenac level in the water with a certain error margin.

\subsection{Uncontrolled Discharges}

60 waste water treatment plants receive sewage water from most of the municipalities in the catchment area. Some of them assist towns with fewer than 150 inhabitants; therefore, theoretically nearly $100 \%$ of sewage water is supposed to pass through a WWTP. However, in reality, some uncontrolled and variable discharges to river water exist from certain urban or industrial areas.

Some measured points of the field campaign could be affected by these uncontrolled discharges. The LLO2 point is located in the upper part in the catchment, downstream of La Baells Lake. There is an industrial channel which supplies water from the reservoir to Berga's city and industry. This channel discharges just before the sampling point LLO2. It is approximately $14 \mathrm{~km}$ in length, $65 \%$ is opened and about $25 \%$ passes through urban or industrial areas. Hence, in this point there is presumably an uncontrolled source of contaminant diclofenac.

Another point probably affected by some uncontrolled discharges is LLO7, close to the discharge point of the Llobregat River to the sea. The river crosses the suburban area of Barcelona, so it is the most inhabited area. Consequently, there is a risk of diclofenac release into this part of Llobregat or into small torrents that conclude in Llobregat.

It is very difficult to estimate the amount of drug released to Berga's Industrial Channel or to the Llobregat River, but it is a potential reason which could justify the underestimated concentration of the model at these two points.

\subsection{Deterministic or Stochastic Approach}

Results indicated a better performance of the stochastic model than the deterministic model, according to mean root square error criterion. However, the lack of accuracy of the deterministic model could be mainly due to the limited availability of reliable data for some variables, such as, flow values. Therefore, a deterministic approach should be the most accurate one if the aim is to estimate the concentrations for a certain day or specific time, while at the same time there is accurate hydrological data available for this specific moment.

An important advantage of the stochastic model is the variability data given as concentration results. The standard deviation gives an idea of the uncertainty and variability that exists in a certain point of the river. Thus, the stochastic approach could be the most proper one to predict future substance concentrations, where there is no accurate data available of most variables.

\subsection{Calibrated Parameters}

Diclofenac emission from WWTPs would be a known parameter if there was accurate data on pharmaceutical consumption, human excretion rates and sewage system removal. Unfortunately, due to the little data available, substance emission is one of the parameters to calibrate.

The calibration process estimated that emission in 2010 was between $0.0115 \mathrm{~g} / \mathrm{cap} /$ year (scenario 3) and $0.051 \mathrm{~g} / \mathrm{cap} /$ year (scenario 1), and in 2011 between 0.0115 (scenario 4) and $0.013 \mathrm{~g} / \mathrm{cap} /$ year (scenario 2). This means, that the emission was between $4 \%$ and $17 \%$ of the consumed diclofenac in 2006 (0.787 mg/cap/day). These percentages 
represent a diclofenac fraction which is not removed in the human body and in the sewage system, which agrees with collected literature data.

Nevertheless, another hypothesis is that consumption in 2010 and 2011 increased following the consumption pattern from 1992 to 2006 (Appendix II). An estimation of consumption can be done by approximating the tendency with a second order polynomial relation. As a result 0.836 and $0.847 \mathrm{mg} / \mathrm{cap} /$ day is the estimated consumption for 2010 and 2011, respectively, according to the tendency of available data. At the same time, this consumption increase implies that excretion rates must be smaller and WWTP removal higher, but not in a significant way. Moreover, other drug removal ways could be considered, like degradation in the sewer system. Overall, between $3 \%$ and $16 \%$ of the consumed diclofenac would be released out of the WWTPs, which is still inside the studied intervals from the literature. Therefore, a growth of diclofenac use among the Llobregat Catchment inhabitants is a valid and possible hypothesis.

Consumption data and estimations are gathered in Appendix II.

The natural degradation constant $(K)$ is the second parameter that was calibrated. Literature data provided rate values for diclofenac: a minimum degradation of $0.015 \mathrm{~d}^{-1}$ and maximum degradation of $0.155 \mathrm{~d}^{-1}$. The model proved that constant rates over or under these extreme values do not provide better results. The RMSE was higher for a $\mathrm{K}$ value of $0.001 \mathrm{~d}^{-1}$ or $0.3 \mathrm{~d}^{-1}$. In addition, the model showed the minimum RMSE for the highest degradation rate, $0.155 \mathrm{~d}^{-1}$. Literature suggests very variable data for diclofenac natural degradation. Some authors define diclofenac as a conservative solute (Johnson et al, 2007), while others state it is a rapidly degradable substance (Bendz et al, 2005). In this project, it has been proved that diclofenac can be more properly estimated with a degradation constant close to $0.155 \mathrm{~d}^{-1}$, which is considered a high degradation rate.

\subsection{Lake Model}

Different authors suggest potential degradation of diclofenac in lakes due to photolysis (Buser et al, 1998; Tixier et al, 2003; Kunkel and Radke, 2011). The GREAT-ER model also simulated a nearly 100\% degradation in the three reservoirs of the Llobregat Catchment. However, measured concentrations during field campaigns show concentrations over $0.1 \mathrm{ng} / \mathrm{l}$ downstream of the lakes.

It has been explained in section 2.3.1. that GREAT-ER calculates substance removal in every stretch with the following $1^{\text {st }}$ order decay expression:

$$
\mathrm{R}=1-\mathrm{e}^{-\mathrm{HRT}} \mathrm{T}^{*} \mathrm{~K}
$$

The residence time HRT for lakes is estimated as:

$$
H R T=\frac{V o l}{Q \cdot 3600}
$$

This formula must be applied under a certain basic hypothesis, such as assuming a fully mixed model all over the lake. Nonetheless, there are many factors in reality that prevent the lake from being fully mixed. Firstly, stratification is a common process which divides the lake into two or three layers depending on water temperature and density at different depths. The upper layers are generally warmer and less dense than the bottom layers. At the same time the bottom layers are usually more static. Hence, substance transportation is mainly happening in the upper part of the lake, especially if there is not an important 
sedimentation capacity. This means that diclofenac probably does not move through all parts of the lake, but just through the upper layer. Furthermore, the shape of the lake also affects the water movement. Irregular forms will complicate the substance transport through some parts. These and other factors imply that the volume considered calculating residence time should be smaller than the whole lake volume, and consequently, the real degradation rate in lakes would be smaller too.

Taking into consideration the measured diclofenac concentrations in samples upstream and downstream of Sant Ponç Lake, an estimation of the residence time has been carried out (Appendix III). Considering the GREAT-ER model formulation, calculating entry and exit concentrations with sampling data and assuming an average $\mathrm{K}$ degradation constant $\left(0.079 \mathrm{~d}^{-1}\right)$, the residence time in Sant Ponç Lake should be approximately 143 days. This implies a volume of $1.01 \cdot 10^{6} \mathrm{~m}^{3}$, whereas the first considered volume was of $22.74 \cdot 10^{6} \mathrm{~m}^{3}$. Therefore, according to sampling concentrations just $4.5 \%$ of the real reservoir volume is exposed to the photodegradation process.

Buser et al. (1988) did one of the most significant studies about diclofenac photodegradation in Greifensee Lake. However, some important characteristics can be distinguished between this Swiss lake and the three lakes in the Llobregat Catchment. Greifensee Lake is $150 \cdot 10^{6} \mathrm{~m}^{3}$, while the largest lake in the Llobregat, La Baells, is $109 \cdot 10^{6} \mathrm{~m}^{3}$, which implies a lower residence time. In addition, Greifensee has a maximum depth of 32 meters, while La Baells has approximately $80 \mathrm{~m}$, so more volume can be stratified. These points could support the fact that not the whole lake volume should be considered in the model.

An alternative to the GREAT-ER simple model could be a model which divides the volume in the three dimensions: vertically considering stratification layers and horizontally considering smaller parts according to the lake shape in a plane. As a result, the model would be divided into smaller volumes and the transport between them should be included. This would be an alternative to improve the lake model.

\section{Conclusion}

The GREAT-ER model has been used and calibrated with measured field concentrations in order to predict the occurrence of the diclofenac pharmaceutical in the Llobregat Catchment. The main conclusions are:

- The geo-referenced model is able to estimate concentration values in most sampling points with an acceptable margin of error. The mean factor (simulated concentrations/measured concentrations) of the four scenarios is 1.79 . This value agrees with the results obtained in another modelling study carried out in Switzerland with GREAT-ER model to predict the fate of $\beta$-blocker human pharmaceuticals (Alder et al, 2010), where the resulting factor was 1.6-2.5. Furthermore, the model is able to predict the tendency of diclofenac fate all over the river network.

- Calibrated parameters agree with suggested values by several authors for diclofenac degradation patterns (excretion rates, waste-water treatment plant removal and natural biodegradation) and consumption. However, it should be considered that provided data from literature covers a wide range of values; WWTP removal, for instance, could be from $0 \%$ to $75 \%$.

- The main way to improve model results is to provide more accurate data. Currently, the available data on hydrological variables in the Llobregat Catchment and diclofenac degradation behaviour and 
consumptions is quite limited and uncertain. Research involving emerging contaminants, such as pharmaceuticals and personal care products, started to appear a couple of decades ago, resulting in a wide variety of inaccurate data for different medical drugs.

- A deeper study for the lake model is suggested, due to the differences between simulated and measured concentrations. An alternative model which divides lakes taking into account vertical stratification and horizontal morphology shapes could be the best option to improve the results.

- The GREAT-ER model could be a reliable tool for predicting the fate of emerging contaminants. It is not able to obtain exact concentration values. Nevertheless, the model allows estimating an overall concentration distribution all over the river network, which could be useful for water quality and resources management. Moreover, the stochastic approach introduces variability and uncertainty in the model. Further research with GREAT-ER and more field campaign data could allow a final validation of the model. Therefore, new scenarios under different environmental conditions, such as, scarcity, or future situations with higher pharmaceutical consumption, could be contemplated.

\section{REFERENCES}

Alder AC, Schaffner C, Majewsky M, Klasmeier J, Fenner K.. 2010. Fate of $\beta$-blocker human pharmaceuticals in surface water: Comparison of measured and simulated concentrations in the Glatt Valley Watershed, Switzerland. Water Research. 44: 936-948

Al-Rajab AJ, Sabourin L, Lapen DR, Topp E. 2010. The non-steroidal anti-inflammatory drug diclofenac is readily biodegradable in agricultural soils. Science of the Total Environment. 409: 78-82

Bendz D, Paxéux NA, Ginn TR, Loge FJ. 2005. Occurrence and fate of pharmaceutically active compounds in the environment, a case study: Höje River in Sweden. Journal of Hazardous Materials. 122: 195-204

Boeije G, Vanrolleghem P, Matthies M. 1997. A geo-referenced aquatic exposure prediction methodology for 'down-the-drain' chemicals. Water Science and Technology. 36: 251-258

Buser HR, Poiger T, Müller MD. 1998. Occurrence and fate of the pharmaceutical drug diclofenac in surface waters: rapid photodegradation in a lake. Environmental Science and Technology 32: 3449-3456

Carballa M, Omil F, Lema JM. 2008. Comparison of predicted and measured concentrations of selected pharmaceuticals, fragrances and hormones in Spanish sewage. Chemosphere. 72: 1118-1123

Heberer T. 2002. Tracking persistent pharmaceutical residues from municipal sewage to drinking water. Journal of Hydrology. 266: 175-189

Jiskra M. 2008. Fate of the pharmaceutical diclofenac in the aquatic environment.. Biogeochemistry and Pollutant Dynamics. 21: 1-16

Johnson AC, Keller V, Williams RJ, Young A. 2007. A practical demonstration in modeling diclofenac and propranolol river water concentrations using a GIS hydrology model in a rural UK catchment. Environmnetal Pollution. 146: 155-165

Jones OAH, Voulvoulis N, Lester JN. 2005. Human pharmaceuticals in wastewater treatment processes. Environmental Science and Technology. 35: $401-427$ 
Kunkel U, Radke M. 2011. Reactive tracer test to evaluate the fate of pharmaceuticals in rivers. Environmental Science and Technology. 45: 62966302

Laak TL, Aa M, Houtman CJ, Stocks PG, Wezel AP. 2010. Relating environmental concentrations of pharmaceuticals to consumption: a mass balance approach for the river Rhine. Environment International. 36: 403-409

Lienert J, Gúdel K, Escher BI. 2007. Screening method for ecotoxicological hazard assessment of 42 pharmaceuticals considering human metabolism and excretory routes. Environmental Science and Technology: 41: 4471-4478

Lin K, Gan J. 2011. Sorption and degradation of wastewater-associated non-steroidal anti-inflammatory drugs and antibiotics in soils. Chemosphere. 83 : 240-246

Miege C, Choubert JM, Ribeiro L, Eusèbe M, Coquery M. 2009. Fate of pharmaceuticals and personal care products in wastewater treatment plants - Conception of a database and first results. Environmental Pollution. 157: 1721-1726

Ort C, Hollender J, Schaerer M, Siegrist H. 2009. Model-based evaluation of reduction strategies for micropollutants from wastewater treatment plants in complex river networks. Environmental Science and Technology 43 (2009), 3214-3220

Osorio V, Marcé R, Pérez S, Ginebreda A, Cortina JL, Barceló D. 2012. Occurrence and modeling of pharmaceuticals on a sewage-impacted Mediterranean river and their dynamics under different hydrological conditions. Science of the Total Environment. 440: 3-13

Pal A, Gin KY, Lin AY, Reinhard M. 2010. Impacts of emerging organic contaminants of freshwater resources: review of recent occurrences, sources, fate and effects. Science of the Total Environment. 408: 60626069

Scheneider HT, Nuernberg B, Dietzel K, Brune K. 1990. Biliary elimination of non-steroidal anti-inflammatory drugs in patients. British Journal of Clinical Pharmacology. 2: 127-131

Schowanek D, Webb S. 2000. Examples of exposure assessment simulation for pharmaceuticals in river basins with the GREAT-ER 1.0 system. Proceedings KVIV Seminar 'Pharmaceuticals in the Environment', Brussels

Spanish Agency of Medicaments and Sanitary Products. 2007. Utilización de antiinflamatorios no esteroides (AINE) en España. Publications

Tixier C, Singer HP, Oellers S, Müller SR. 2003. Occurrence and fate of Carbamazepine, clofibric acid, diclofenac, ibuprofen, ketoprofen and naproxen in surface waters. Environmental Science and Technology. 37: 1061-1068

Whelan MJ, Gandolfi C, Bischetti GB. 1999. A simple stochastic model of point source solute transport in rivers based on gauging station data with implications for sampling requirements. Water Research. 33: 3171-3181 
ApPENDix I - RESUlts: CONCENTRATiON TABLES, RMSE, CSIM/CMEAS FACTOR, EMISSION, K (FOR EACH SCENARIO'S BEST RESULT)

The following tables show the numerical results after calibration. In each scenario the root-mean-square error (RMSE) and F factor is calculated with these expressions:

$$
\begin{aligned}
& R M S E=\sqrt{\frac{\sum(\text { Cestim. }- \text { Cmeas. })^{2}}{14}} \\
& F=\frac{\text { Cestim. }}{\text { Cmeas. }}
\end{aligned}
$$

Where Cestim. is the estimated concentration by the GREAT-ER model and Cmeas. is the measured concentration through field samplings.

Table 6. GREAT-ER model results and measured concentrations in every sampling point, and for each scenario. Error estimation through $F$ and $R M S$. All units in $n g / l$.

\begin{tabular}{|l|r|}
\hline \multicolumn{2}{|c|}{ SCENARIO 1. Deterministic model. 2010} \\
\hline $\mathrm{K}(\mathrm{h}-1)$ & 0.006458333 \\
\hline Emission (kg/cap/year) & $5.05569 \mathrm{E}-05$ \\
\hline
\end{tabular}

\begin{tabular}{|l|r|r|r|r|}
\hline $\begin{array}{c}\text { Diclofenac } \\
\text { Concentra- } \\
\text { tions (ng/l) }\end{array}$ & $\begin{array}{c}\text { GREATER } \\
\text { model estima- } \\
\text { tion }\end{array}$ & $\begin{array}{c}\text { Sampling } \\
\text { measurements }\end{array}$ & $\begin{array}{c}\text { F (Ces- } \\
\text { tim./Cmeas. } \\
\text { ) }\end{array}$ & RMSE \\
\hline LLO1 & 0.501 & 6.061 & -0.917 & 30.913 \\
\hline LLO2 & 0.000 & 6.061 & -1.000 & 36.731 \\
\hline LLO3 & 11.806 & 9.726 & 0.214 & 4.323 \\
\hline CAR1 & 0.000 & 3.636 & -1.000 & 13.223 \\
\hline CAR2 & 4.283 & 3.636 & 0.178 & 0.418 \\
\hline CAR3 & 7.773 & 4.800 & 0.619 & 8.838 \\
\hline CAR4 & 26.812 & 6.061 & 3.424 & 430.615 \\
\hline LLO4 & 18.564 & 12.800 & 0.450 & 33.219 \\
\hline LLO5 & 25.459 & 18.484 & 0.377 & 48.648 \\
\hline ANO1 & 40.530 & 5.895 & 5.876 & 1199.628 \\
\hline ANO2 & 78.878 & 129.053 & -0.389 & 2517.524 \\
\hline ANO3 & 37.779 & 50.737 & -0.255 & 167.894 \\
\hline LLO6 & 24.575 & 15.853 & 0.550 & 76.080 \\
\hline LLO7 & 55.899 & 62.105 & -0.100 & 38.518 \\
\hline & & & 0.573 & $\mathbf{1 8 . 1 3 9}$ \\
\hline
\end{tabular}




\begin{tabular}{|l|r|}
\hline \multicolumn{2}{|c|}{ SCENARIO 2. Deterministic model. 2011} \\
\hline $\mathrm{K}(\mathrm{h}-1)$ & 0.006458333 \\
\hline Emission (kg/cap/year) & $1.29265 \mathrm{E}-05$ \\
\hline
\end{tabular}

\begin{tabular}{|l|r|r|r|r|}
\hline $\begin{array}{c}\text { Diclofenac } \\
\text { Concentrations } \\
\text { (ng/l) }\end{array}$ & $\begin{array}{c}\text { GREATER } \\
\text { model estima- } \\
\text { tion }\end{array}$ & $\begin{array}{c}\text { Sampling } \\
\text { measurements }\end{array}$ & $\begin{array}{c}\text { F (Ces- } \\
\text { tim./Cmeas. }\end{array}$ & RMSE \\
\hline LLO1 & 0.40 & 0.539 & -0.263 & 0.020 \\
\hline LLO2 & 0.00 & 0.469 & -1.000 & 0.220 \\
\hline LLO3 & 5.88 & 4.484 & 0.311 & 1.945 \\
\hline CAR1 & 0.00 & 0.863 & -1.000 & 0.745 \\
\hline CAR2 & 1.82 & 0.248 & 6.306 & 2.454 \\
\hline CAR3 & 3.10 & 4.905 & -0.368 & 3.254 \\
\hline CAR4 & 14.90 & 11.916 & 0.250 & 8.888 \\
\hline LLO4 & 10.49 & 6.737 & 0.557 & 14.079 \\
\hline LLO5 & 15.31 & 4.842 & 2.162 & 109.640 \\
\hline ANO1 & 15.46 & 1.493 & 9.360 & 195.199 \\
\hline ANO2 & 90.38 & 120.000 & -0.247 & 877.167 \\
\hline ANO3 & 71.63 & 54.526 & 0.314 & 292.399 \\
\hline LL06 & 15.17 & 9.453 & 0.605 & 32.665 \\
\hline LLO7 & 42.07 & 280.000 & -0.850 & 56612.112 \\
\hline & & & 1.153 & 64.449 \\
\hline
\end{tabular}

\begin{tabular}{|l|r|}
\hline \multicolumn{2}{|c|}{ SCENARIO 3. Stochastic model. 2010 } \\
\hline $\mathrm{K}(\mathrm{h}-1)$ & 0.006458333 \\
\hline Emission (kg/cap/year) & $1.14902 \mathrm{E}-05$ \\
\hline
\end{tabular}

\begin{tabular}{|c|c|c|c|c|c|}
\hline \multirow{2}{*}{$\begin{array}{l}\text { Diclofenac } \\
\text { Concentra- } \\
\text { tions (ng/l) }\end{array}$} & \multicolumn{2}{|c|}{$\begin{array}{l}\text { GREATER model esti- } \\
\text { mation }\end{array}$} & \multirow{2}{*}{$\begin{array}{c}\text { Sampling } \\
\text { measure- } \\
\text { ments }\end{array}$} & \multirow{2}{*}{$\begin{array}{c}F \text { (Ces- } \\
\text { tim./Cmeas.) }\end{array}$} & \multirow{2}{*}{ RMSE } \\
\hline & $\begin{array}{l}\text { Mean } \\
\text { Value }\end{array}$ & $\begin{array}{l}\text { Standard } \\
\text { Deviation }\end{array}$ & & & \\
\hline LLO1 & 0.198 & 0.000 & 6.061 & -0.967 & 34.367 \\
\hline LLO2 & 0.000 & 0.000 & 6.061 & -1.000 & 36.731 \\
\hline LLO3 & 5.776 & & 9.726 & -0.406 & 15.605 \\
\hline CAR1 & 0.000 & 0.000 & 3.636 & -1.000 & 13.223 \\
\hline CAR2 & 1.700 & 0.960 & 3.636 & -0.533 & 3.750 \\
\hline CAR3 & 3.540 & 2.250 & 4.800 & -0.263 & 1.588 \\
\hline CAR4 & 13.743 & 3.983 & 6.061 & 1.268 & 59.023 \\
\hline LLO4 & 9.281 & 3.970 & 12.800 & -0.275 & 12.386 \\
\hline LLO5 & 14.793 & 7.948 & 18.484 & -0.200 & 13.625 \\
\hline ANO1 & 19.961 & 0.000 & 5.895 & 2.386 & 197.865 \\
\hline ANO2 & 100.150 & 64.025 & 129.053 & -0.224 & 835.362 \\
\hline ANO3 & 79.584 & 64.650 & 50.737 & 0.569 & 832.159 \\
\hline LLO6 & 14.710 & 7.900 & 15.853 & -0.072 & 1.306 \\
\hline LLO7 & 67.665 & 72.560 & 62.105 & 0.090 & 30.911 \\
\hline & & & & -0.045 & 12.212 \\
\hline
\end{tabular}




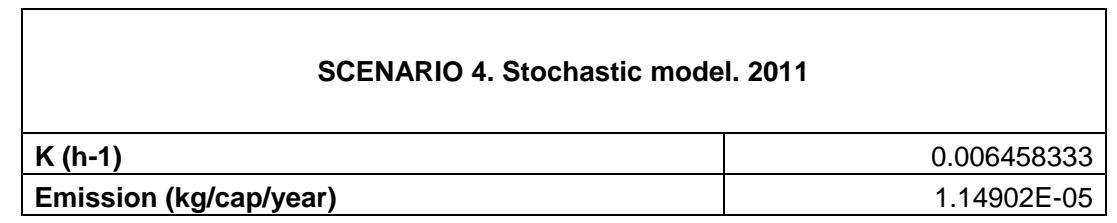

\begin{tabular}{|c|c|c|c|c|c|}
\hline \multirow{2}{*}{$\begin{array}{l}\text { Diclofenac } \\
\text { Concentra- } \\
\text { tions (ng/l) }\end{array}$} & \multicolumn{2}{|c|}{$\begin{array}{c}\text { GREATER model estima- } \\
\text { tion }\end{array}$} & \multirow{2}{*}{$\begin{array}{c}\text { Sampling } \\
\text { measure- } \\
\text { ments }\end{array}$} & \multirow{2}{*}{$\begin{array}{c}F \text { (Ces- } \\
\text { tim./Cmeas.) }\end{array}$} & \multirow{2}{*}{ RMSE } \\
\hline & Mean Value & $\begin{array}{l}\text { Standard } \\
\text { Deviation }\end{array}$ & & & \\
\hline LL01 & 0.198 & 0.000 & 0.539 & -0.632 & 0.116 \\
\hline LLO2 & 0.000 & 0.000 & 0.469 & -1.000 & 0.220 \\
\hline LLO3 & 5.776 & & 4.484 & 0.288 & 1.669 \\
\hline CAR1 & 0.000 & 0.000 & 0.863 & -1.000 & 0.745 \\
\hline CAR2 & 1.700 & 0.960 & 0.248 & 5.843 & 2.107 \\
\hline CAR3 & 3.540 & 2.250 & 4.905 & -0.278 & 1.864 \\
\hline CAR4 & 13.743 & 3.983 & 11.916 & 0.153 & 3.340 \\
\hline LLO4 & 9.281 & 3.970 & 6.737 & 0.378 & 6.471 \\
\hline LLO5 & 14.793 & 7.948 & 4.842 & 2.055 & 99.020 \\
\hline ANO1 & 19.961 & 0.000 & 1.493 & 12.373 & 341.088 \\
\hline ANO2 & 100.150 & 64.025 & 120.000 & -0.165 & 394.022 \\
\hline ANO3 & 79.584 & 64.650 & 54.526 & 0.460 & 627.888 \\
\hline LLO6 & 14.710 & 7.900 & 9.453 & 0.556 & 27.640 \\
\hline LLO7 & 67.665 & 72.560 & 280.000 & -0.758 & $\begin{array}{r}45086.15 \\
2 \\
\end{array}$ \\
\hline & & & & 1.305 & 57.689 \\
\hline
\end{tabular}




\section{APPENDiX II - CONSUMPTION: DATA AND ESTIMATIONS \\ Consumption Data}

The Spanish Agency of Medicaments and Sanitary Products published, in 2007 , a report about the use of non-steroidal anti-inflammatory drugs in Spain (there have not been any later publications about the same topic). This article provided diclofenac consumption data from 1992 to 2006.

Table 7. Use of diclofenac, in DDD per 1000 inhabitants and per day. Spanish Agency of Medicaments and Sanitary Products (AEM), 2007.

\begin{tabular}{|r|r|r|r|r|r|r|r|}
\hline Year & 1992 & 1993 & 1994 & 1995 & 1996 & 1997 & 1998 \\
\hline $\begin{array}{l}\text { DDD/1000 } \\
\text { inhab./day }\end{array}$ & 6.74 & 6.35 & 6.31 & 6.39 & 6.3 & 6.33 & 6.54 \\
\hline 1999 & 2000 & 2001 & 2002 & 2003 & 2004 & 2005 & 2006 \\
\hline 7.6 & 7.89 & 7.57 & 7.52 & 7.59 & 7.84 & 7.33 & 7.87 \\
\hline
\end{tabular}

DDD is the Defined Daily Dose, which for diclofenac is $100 \mathrm{mg}$.

\section{Polynomial Relation}

This data can be adjusted with a second order polynomial relation in order to estimate the consumption in further years, in particular, in 2010 and 2011 .

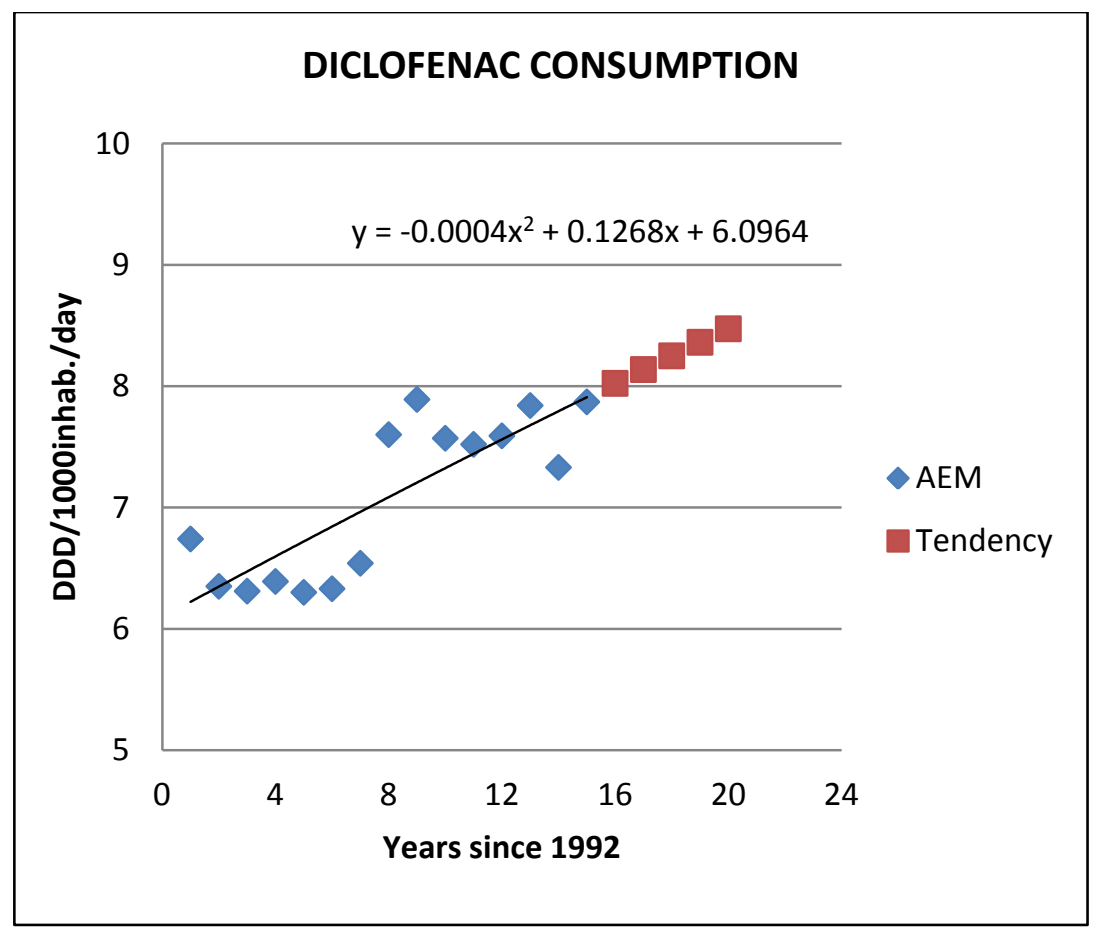

Figure 9. Graphic with diclofenac consumption data (AEM) and estimated values with a secondary order polynomial.

Table 7. Estimated values for diclofenac consumption 2007-2011.

\begin{tabular}{|l|r|r|r|r|r|}
\hline Year & $\mathbf{2 0 0 7}$ & $\mathbf{2 0 0 8}$ & $\mathbf{2 0 0 9}$ & $\mathbf{2 0 1 0}$ & $\mathbf{2 0 1 1}$ \\
\hline $\begin{array}{l}\text { DDD/1000 } \\
\text { inhab./day }\end{array}$ & 8.0228 & 8.1364 & 8.2492 & 8.3612 & 8.4724 \\
\hline
\end{tabular}


Emission: Consumption, Excretion Rates and WWTPs Removal

Diclofenac emission was one the parameters to be calibrated. Emission involves three factors: drug consumption, human body excretion rate and waste water treatment plants removal. Taking into account the emission calibrated values and the collected data for these factors, a new estimation can be done, in particular, for the Llobregat Catchment.

Two hypotheses are considered. In the first one, the consumed diclofenac in 2010 and 2011 is the same as in 2006, which is the latest date with available data. In the second one, consumption is estimated from the polynomial relation for 2010 and 2011. Afterwards, some excretion rates and WWTP removal is suggested according to literature information, and applying this expression:

Emission $=$ Consumption $\cdot$ ExcretionRate $\cdot(1-$ WWTPRemoval $)$

Table 8. Diclofenac consumption: data from the Spanish Agency of Medicaments and Sanitary Products and estimated consumption according to the polynomial relation. Estimated excretion rates and WWTP removal efficiency. Calibrated emission (for each scenario).

\begin{tabular}{|l|r|r|}
\hline Scenario 1. Deterministic model. 2010 & \multicolumn{1}{|c|}{ Published data } & \multicolumn{1}{c|}{ Estimated value } \\
\hline Consumption (mg/cap/day) & 0.787 & 0.836 \\
\hline Consumption (kg/cap/year) & $2.87 \mathrm{E}-04$ & $3.05 \mathrm{E}-04$ \\
\hline Rexcretion & 0.22 & 0.22 \\
\hline Rwwtp & 0.20 & 0.25 \\
\hline Emission (kg/cap/year) & $5.06 \mathrm{E}-05$ & $5.06 \mathrm{E}-05$ \\
\hline
\end{tabular}

\begin{tabular}{|l|r|r|}
\hline Scenario 2. Deterministic model. 2011 & \multicolumn{1}{|c|}{ Published data } & \multicolumn{1}{c|}{ Estimated value } \\
\hline Consumption (mg/cap/day) & 0.787 & 0.847 \\
\hline Consumption (kg/cap/year) & $2.87 \mathrm{E}-04$ & $3.09 \mathrm{E}-04$ \\
\hline Rexcretion & 0.13 & 0.13 \\
\hline Rwwtp & 0.65 & 0.68 \\
\hline Emission (kg/cap/year) & $1.29 \mathrm{E}-05$ & $1.29 \mathrm{E}-05$ \\
\hline
\end{tabular}

\begin{tabular}{|l|r|r|}
\hline \multicolumn{1}{|c|}{ Scenario 3. Stochastic model. 2010 } & Published data & \multicolumn{1}{c|}{ Estimated value } \\
\hline Consumption (mg/cap/day) & 0.787 & 0.836 \\
\hline Consumption (kg/cap/year) & $2.87 \mathrm{E}-04$ & $3.05 \mathrm{E}-04$ \\
\hline Rexcretion & 0.10 & 0.10 \\
\hline Rwwtp & 0.60 & 0.62 \\
\hline Emission (kg/cap/year) & $1.15 \mathrm{E}-05$ & $1.15 \mathrm{E}-05$ \\
\hline
\end{tabular}

\begin{tabular}{|l|r|r|}
\hline \multicolumn{1}{|c|}{ Scenario 4. Stochastic model. 2011 } & Published data & \multicolumn{1}{c|}{ Estimated value } \\
\hline Consumption (mg/cap/day) & 0.787 & 0.847 \\
\hline Consumption (kg/cap/year) & $2.87 \mathrm{E}-04$ & $3.09 \mathrm{E}-04$ \\
\hline Rexcretion & 0.10 & 0.10 \\
\hline Rwwtp & 0.60 & 0.63 \\
\hline Emission (kg/cap/year) & $1.15 \mathrm{E}-05$ & $1.15 \mathrm{E}-05$ \\
\hline
\end{tabular}


The estimated excretion rates and WWTP removal values can be different to the ones shown in table 8 , there are many possible combination. The one suggested in this project have been chosen considering the usual values from literature. As a result, the excretion rates vary between $10-22 \%$ and the removal efficiency between $20-63 \%$.

Both hypotheses imply very similar WWTP removal values which agree with researched data. This means, that both hypothesis are valid and that the consumption in 2010 and 2011 could had been between 0.787 $0.847 \mathrm{mg} / \mathrm{cap} /$ day.

Nevertheless, it must be considered that all these parameters are general values. Consumption data is referred to the entire country of Spain, but it can vary considerably among different areas. WWT removal efficiency can also vary depending on each plant treatments. Therefore, these value-intervals will probably vary in other catchment areas. 


\section{APPENDIX III - LAKE MODEL: HRT ESTIMATION}

It has been explained in section 4.4 that the GREAT-ER lake model does not agree with measured sampling concentrations. GREAT-ER estimated a nearly $100 \%$ degradation of diclofenac in the three reservoirs of the Llobregat Catchment; whereas sampling values measured concentrations are above $0.1 \mathrm{ng} / \mathrm{l}$.

An overestimation of the residence time in the lakes could be one of the main reasons that provokes this difference. Therefore, a new manual calculation has been done to predict the residence time of Sant Ponç Reservoir according to sampling data of September 2011, $2^{\text {nd }}$ Campaign (values from $1^{\text {st }}$ Campaign in LLO1, LLO2 and CAR2 are not considered reliable).

For this calculation diagram in figure 10 has been considered, where Sant Ponç Lake is represented, with its entry river and exit river. Point A represents CAR1 sampling point, $B$ the entry point to the lake, $C$ the exit point and D CAR2 sampling point.

Concentration in A and D is fixed according to CAR1 and CAR2 sampling values: 0.8632 and $0.2484 \mathrm{ng} / \mathrm{l}$, respectively. Therefore, the chemical mass flux $(\mathrm{m})$ can be calculated in $\mathrm{A}$ and $\mathrm{D}$ point:

$\mathrm{C}_{\mathrm{A}}=0.8632 \mathrm{ng} / \mathrm{l}$

$\mathrm{Q}_{\mathrm{A}}=1.9615 \mathrm{~m}^{3} / \mathrm{s}$ (known value)

$\mathrm{m}_{\mathrm{A}}=\mathrm{C}_{\mathrm{A}} \cdot \mathrm{Q}_{\mathrm{A}}=1686.91 \mathrm{ng} / \mathrm{s}$

$\mathrm{C}_{\mathrm{D}}=0.2484 \mathrm{ng} / \mathrm{l}$

$\mathrm{Q}_{\mathrm{D}}=2.1048 \mathrm{~m}^{3} / \mathrm{s}$ (known value)

$\mathrm{m}_{\mathrm{D}}=\mathrm{C}_{\mathrm{D}} \cdot \mathrm{Q}_{\mathrm{D}}=5228.3 \mathrm{ng} / \mathrm{s}$

Mass flux in B is estimated from mass flux value in A point and with GREAT-ER model formulation, which results in $1661.6 \mathrm{ng} / \mathrm{s}$ in B.

In order to calculate diclofenac mass flux in $\mathrm{C}$ the discharge of two waste water treatment plants must be taken into consideration (Solsona and Riner-Freixenet). According to the calibrated diclofenac consumption and to the attended population by two plants, they discharge $4202.2 \mathrm{ng} / \mathrm{s}$ of diclofenac.

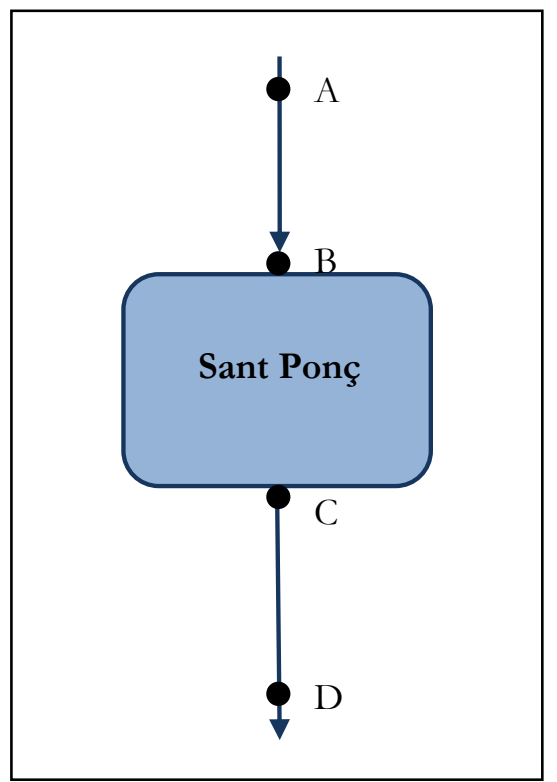

Figure 10. Sant Ponç Lake diagram for HRT estimation. 
Considering this emission and the first-order-decay formula of the GREAT-ER model, diclofenac mass in C points is $1036.7 \mathrm{ng} / \mathrm{s}$. Hence, mass flux in the entry $\left(\mathrm{m}_{\mathrm{B}}\right)$ and exit $\left(\mathrm{m}_{\mathrm{C}}\right)$ of the lake have been estimated according to field sample values. The lake residence time will be calculated with same formula as the GREAT-ER model, considering the mass flux in B and C:

$\mathrm{R}_{\text {lake }}=1-\mathrm{e}^{-\mathrm{HRT}}{ }^{* \mathrm{~K}}$, and at the same time $\mathrm{m}_{\mathrm{C}}=\mathrm{m}_{\mathrm{B}} \cdot\left(1-\mathrm{R}_{\text {lake }}\right)$. Therefore:

$\mathrm{m}_{\mathrm{B}}=1661.6 \mathrm{ng} / \mathrm{l}$

$\mathrm{m}_{\mathrm{C}}=1036.7 \mathrm{ng} / \mathrm{l}$

$R_{\text {lake }}=1-\frac{m_{C}}{m_{B}}=0.376=1-e^{-K \cdot H R T}$

$\mathrm{K}=0.079 \mathrm{~d}^{-1}=0.0033333 \mathrm{~h}^{-1}$ (average value, known value)

$H R T=\frac{-\ln (1-R)}{K}=143$ days

$\mathrm{Q}=1.96 \mathrm{~m}^{3} / \mathrm{s}$ (known value)

$H R T=\frac{V o l}{Q \cdot 3600}$

Vol $=1.012 \cdot 10^{6} \mathrm{~m}^{3}$

Thus, the residence time in Sant Ponç Lake is 143 days according to sampling concentrations values, which implies a volume of $1.01 \cdot 10^{6} \mathrm{~m}^{3}$. 


\section{APPENDIX IV - VELOCITY FORMULA}

Velocity in every stretch of the Llobregat River network is required in order to create the input files for GREAT-ER, which affects diclofenac degradation. In this section, the background and formulation used to obtain velocity values is explained.

The background belongs to the TETIS model, which is a distributed hydrological model used in the GIMHA group (Research Group of Hydrological and Environmental Modelling) from the Polytechnic University of Valencia.

The origin of the velocity formula comes from the Manning expression, which is an empirical formula for open channel flow:

$v=\frac{R^{2 / 3} \cdot S_{0}{ }^{1 / 2}}{n}$

Where, $\mathrm{v}$ is the velocity, $\mathrm{R}$ is the hydraulic radius, $\mathrm{S}_{0}$ is the slope of the water surface and $\mathrm{n}$ is the Manning coefficient which takes into account surface roughness.

TETIS model considers some expressions for hydraulic geometry that come from Leopold and Madock (1953) and Leopold, Wolman and Miller (1963) expressions. They establish a relation between the hydraulic geometry, water flow and drained area in a point. These relations imply the use of nine parameters for the hydraulic geometry, which can be introduced in Manning expression and generate the following formula for velocity:

$$
v=\left[\frac{A^{(2 / 3-\xi \theta)\left(1-\varepsilon_{2}\right)} \cdot S_{0}^{(1 / 2-\xi \theta)}}{c_{n} \cdot c_{d}^{\xi} \cdot\left(c_{1} \cdot \kappa^{\left(\varepsilon_{1}-\varepsilon_{2}\right)} \cdot \Lambda^{\varphi\left(\varepsilon_{1}-\varepsilon_{2}\right)}\right)^{(2 / 3-\xi \theta)}}\right]^{\frac{1}{\left(1+\varepsilon_{2}(2 / 3-\xi \theta)\right)}}
$$

A is the wet area of the section and $\Lambda$ is the drained area. The rest of parameters refer to the hydraulic geometry and their values have been adjusted to Llobregat Catchment in another research study done in GIMHA.

Table 9. Parameters of hydraulic geometry adjusted in Llobregat Catchment.

\begin{tabular}{|l|l|}
\hline $\mathbf{K}$ & 1.29680002 \\
\hline $\boldsymbol{\phi}$ & 0.75709999 \\
\hline $\mathbf{C}_{1}$ & 3.13010001 \\
\hline $\boldsymbol{\varepsilon}_{1}$ & 0.50880003 \\
\hline $\boldsymbol{\varepsilon}_{\mathbf{2}}$ & 0.32530001 \\
\hline $\mathbf{C}_{\boldsymbol{d}}$ & 6.51560020 \\
\hline $\boldsymbol{\theta}$ & 0.65480000 \\
\hline $\boldsymbol{c}_{\boldsymbol{n}}$ & 0.04700000 \\
\hline $\boldsymbol{\xi}$ & 0.16670001 \\
\hline
\end{tabular}

Considering that $\mathrm{A}=\mathrm{Q} / \mathrm{v}$ and an overall correcting factor, the new expression for velocity is: 


$$
v=F C \cdot\left[\frac{Q^{(2 / 3-\xi \theta)\left(1-\varepsilon_{2}\right)} \cdot S_{0}^{(1 / 2-\xi \theta)}}{c_{n} \cdot c_{d}^{\xi} \cdot\left(c_{1} \cdot \kappa^{\left(\varepsilon_{1}-\varepsilon_{2}\right)} \cdot \Lambda^{\varphi\left(\varepsilon_{1}-\varepsilon_{2}\right)}\right)^{(2 / 3-\xi \theta)}}\right]^{\frac{1}{1+\frac{2}{3}-\xi \theta}}
$$

The correcting factor FC has been calibrated according to some velocity data provided by the HEC-RAS model in the Llobregat Catchment.

Introducing geometric parameters and adjusted value for FC (0.399), the final formula to define the velocity in every stretch of the river depends on the water flow, slope and drained area:

$$
v=1.520567 \cdot Q^{0.24151} \cdot S_{0}^{0.25094} \cdot \Lambda^{-0.04973}
$$

In order to obtain the velocity of every river stretch in Llobregat, a new raster layer in ArcGis has been generated applying this formula. 


\section{APPENDiX V - STRETCHES, FLOW AND VELOCITY DISTRIBUTION IN THE LLOBREGAT CATCHMENT}

The GREAT-ER model requires a separation and identification of the river network into stretches. The distribuion of stretches have been done taking into account the following factors:

- Bifurcation points

- Confluence points

- WWTP discharges

- Water extractions (demands)

- Sampling points

Figure 11 shows the stretches' identification used in this thesis.

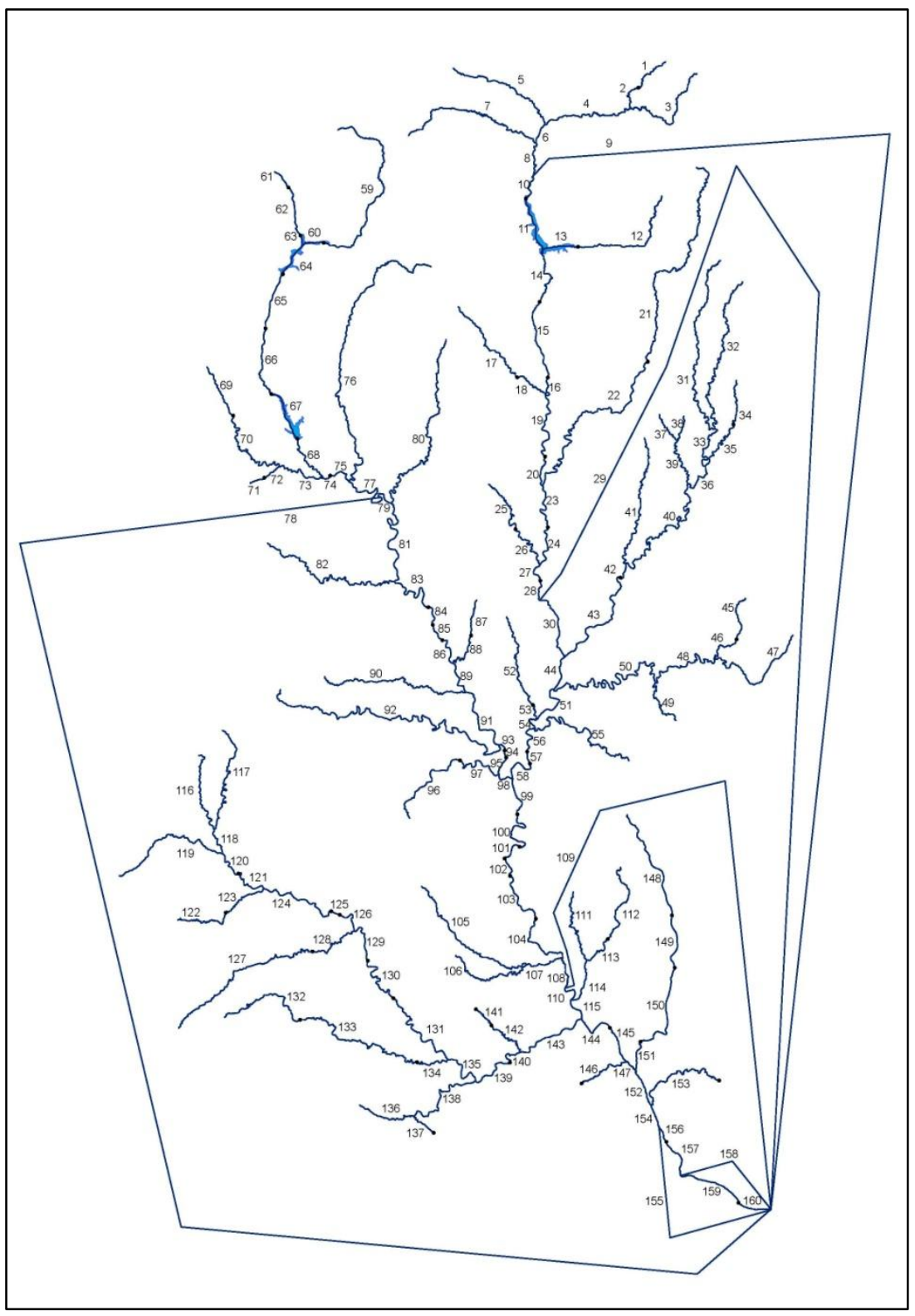

Figure 11. Llobregat River network: stretches distribution and identification. 
Flow value have been calculated for each river stretch considering these factors:

- Measured water flows in control stations

- WW'TPs' discharged water

- Demanded water for drinking or irrigation supplying

- Addition of natural water flow in confluences

Table 10. $Q$ Flow values $\left(\mathrm{m}^{3} / \mathrm{s}\right)$ for every river stretch, on September 22, 2010, September 13, 2011 and the average values in the years 2000-2012 used in the stochastic model.

\begin{tabular}{|c|c|c|c|}
\hline StretchID & Q 2010 & Q 2011 & Q stochastic \\
\hline 1 & 0.52 & 0.17 & 0.30 \\
\hline 2 & 0.52 & 0.17 & 0.30 \\
\hline 3 & 0.81 & 0.32 & 0.50 \\
\hline 4 & 1.33 & 0.49 & 0.80 \\
\hline 5 & 1.26 & 0.50 & 0.78 \\
\hline 6 & 2.62 & 1.02 & 1.60 \\
\hline 7 & 0.60 & 1.04 & 0.44 \\
\hline 8 & 3.22 & 2.06 & 2.04 \\
\hline 9 & 1.38 & 1.02 & 1.19 \\
\hline 10 & 1.84 & 1.04 & 0.85 \\
\hline 11 & 1.85 & 1.04 & 0.86 \\
\hline 12 & 0.38 & 0.21 & 0.17 \\
\hline 13 & 0.38 & 0.21 & 0.17 \\
\hline 14 & 3.00 & 5.55 & 3.64 \\
\hline 15 & 3.05 & 5.60 & 3.69 \\
\hline 16 & 3.06 & 5.61 & 3.70 \\
\hline 17 & 0.47 & 0.10 & 0.31 \\
\hline 18 & 0.47 & 0.10 & 0.31 \\
\hline 19 & 3.54 & 5.71 & 4.01 \\
\hline 20 & 3.55 & 5.72 & 4.02 \\
\hline 21 & 1.42 & 0.31 & 0.93 \\
\hline 22 & 2.44 & 0.52 & 1.60 \\
\hline 23 & 5.99 & 6.25 & 5.62 \\
\hline 24 & 6.00 & 6.26 & 5.63 \\
\hline 25 & 0.25 & 0.02 & 0.23 \\
\hline 26 & 0.25 & 0.02 & 0.23 \\
\hline 27 & 6.25 & 6.28 & 5.87 \\
\hline 28 & 6.25 & 6.29 & 5.87 \\
\hline 29 & 1.52 & 2.73 & 0.81 \\
\hline 30 & 4.74 & 3.56 & 5.07 \\
\hline 31 & 0.29 & 0.03 & 0.09 \\
\hline 32 & 0.27 & 0.03 & 0.09 \\
\hline 33 & 0.56 & 0.06 & 0.18 \\
\hline 34 & 0.13 & 0.01 & 0.04 \\
\hline
\end{tabular}




\begin{tabular}{|c|c|c|c|}
\hline 35 & 0.13 & 0.02 & 0.04 \\
\hline 36 & 0.69 & 0.08 & 0.23 \\
\hline 37 & 0.06 & 0.01 & 0.02 \\
\hline 38 & 0.05 & 0.01 & 0.02 \\
\hline 39 & 0.11 & 0.02 & 0.04 \\
\hline 40 & 0.80 & 0.10 & 0.26 \\
\hline 41 & 0.30 & 0.03 & 0.09 \\
\hline 42 & 1.09 & 0.13 & 0.36 \\
\hline 43 & 1.10 & 0.13 & 0.36 \\
\hline 44 & 5.86 & 3.72 & 5.45 \\
\hline 45 & 0.21 & 0.01 & 0.00 \\
\hline 46 & 0.23 & 0.03 & 0.02 \\
\hline 47 & 0.40 & 0.03 & 0.01 \\
\hline 48 & 0.63 & 0.06 & 0.03 \\
\hline 49 & 0.45 & 0.03 & 0.01 \\
\hline 50 & 1.08 & 0.09 & 0.04 \\
\hline 51 & 6.94 & 3.81 & 5.49 \\
\hline 52 & 0.29 & 0.02 & 0.01 \\
\hline 53 & 0.36 & 0.09 & 0.07 \\
\hline 54 & 7.30 & 3.89 & 5.57 \\
\hline 55 & 0.58 & 0.05 & 0.01 \\
\hline 56 & 7.89 & 3.94 & 5.57 \\
\hline 57 & 7.89 & 3.94 & 5.57 \\
\hline 58 & 7.89 & 3.95 & 5.58 \\
\hline 59 & 1.07 & 0.02 & 0.66 \\
\hline 60 & 1.07 & 0.02 & 0.66 \\
\hline 61 & 0.19 & 0.00 & 0.18 \\
\hline 62 & 0.27 & 0.01 & 0.16 \\
\hline 63 & 0.27 & 0.01 & 0.17 \\
\hline 64 & 1.34 & 0.03 & 0.82 \\
\hline 65 & 2.00 & 1.50 & 2.02 \\
\hline 66 & 2.43 & 1.96 & 2.19 \\
\hline 67 & 2.43 & 1.96 & 2.19 \\
\hline 68 & 3.00 & 1.96 & 2.49 \\
\hline 69 & 0.07 & 0.08 & 0.01 \\
\hline 70 & 0.09 & 0.10 & 0.03 \\
\hline 71 & 0.03 & 0.04 & 0.00 \\
\hline 72 & 0.03 & 0.04 & 0.00 \\
\hline 73 & 0.12 & 0.14 & 0.03 \\
\hline 74 & 3.12 & 2.10 & 2.52 \\
\hline 75 & 3.12 & 2.10 & 2.52 \\
\hline 76 & 0.47 & 0.43 & 0.20 \\
\hline 77 & 3.59 & 2.53 & 2.71 \\
\hline 78 & 0.02 & 0.19 & 0.10 \\
\hline 79 & 3.58 & 2.35 & 2.63 \\
\hline
\end{tabular}




\begin{tabular}{|c|c|c|c|}
\hline 80 & 0.03 & 0.07 & 0.04 \\
\hline 81 & 3.60 & 2.41 & 2.67 \\
\hline 82 & 0.01 & 0.05 & 0.04 \\
\hline 83 & 3.61 & 2.46 & 2.70 \\
\hline 84 & 3.63 & 2.48 & 2.72 \\
\hline 85 & 3.63 & 2.48 & 2.72 \\
\hline 86 & 3.63 & 2.48 & 2.72 \\
\hline 87 & 0.13 & 0.01 & 0.00 \\
\hline 88 & 0.13 & 0.01 & 0.00 \\
\hline 89 & 3.76 & 2.49 & 2.72 \\
\hline 90 & 0.65 & 0.04 & 0.01 \\
\hline 91 & 4.41 & 2.53 & 2.74 \\
\hline 92 & 1.63 & 0.11 & 0.03 \\
\hline 93 & 6.04 & 2.63 & 2.76 \\
\hline 94 & 6.37 & 2.96 & 3.10 \\
\hline 95 & 6.37 & 2.96 & 3.10 \\
\hline 96 & 0.66 & 0.04 & 0.01 \\
\hline 97 & 0.67 & 0.05 & 0.02 \\
\hline 98 & 7.04 & 3.01 & 3.11 \\
\hline 99 & 14.93 & 6.96 & 8.69 \\
\hline 100 & 14.93 & 6.96 & 8.69 \\
\hline 101 & 14.96 & 6.99 & 8.72 \\
\hline 102 & 14.96 & 6.99 & 8.72 \\
\hline 103 & 14.98 & 7.02 & 8.75 \\
\hline 104 & 14.98 & 7.02 & 8.75 \\
\hline 105 & 0.54 & 0.02 & 0.01 \\
\hline 106 & 0.48 & 0.02 & 0.01 \\
\hline 107 & 1.02 & 0.04 & 0.02 \\
\hline 108 & 16.00 & 7.06 & 8.76 \\
\hline 109 & 2.55 & 1.64 & 2.13 \\
\hline 110 & 13.67 & 5.63 & 6.84 \\
\hline 111 & 0.42 & 0.02 & 0.01 \\
\hline 112 & 0.47 & 0.02 & 0.00 \\
\hline 113 & 0.48 & 0.03 & 0.02 \\
\hline 114 & 0.91 & 0.05 & 0.03 \\
\hline 115 & 14.57 & 5.68 & 6.87 \\
\hline 116 & 0.03 & 0.03 & 0.02 \\
\hline 117 & 0.04 & 0.03 & 0.02 \\
\hline 118 & 0.08 & 0.06 & 0.04 \\
\hline 119 & 0.04 & 0.03 & 0.02 \\
\hline 120 & 0.12 & 0.09 & 0.06 \\
\hline 121 & 0.12 & 0.09 & 0.06 \\
\hline 122 & 1.07 & 0.02 & 0.09 \\
\hline 123 & 1.07 & 0.03 & 0.09 \\
\hline 124 & 1.18 & 0.11 & 0.15 \\
\hline
\end{tabular}




\begin{tabular}{|c|c|c|c|}
\hline 125 & 1.38 & 0.31 & 0.35 \\
\hline 126 & 1.38 & 0.31 & 0.35 \\
\hline 127 & 1.98 & 0.04 & 0.17 \\
\hline 128 & 1.98 & 0.05 & 0.17 \\
\hline 129 & 3.36 & 0.36 & 0.52 \\
\hline 130 & 3.42 & 0.41 & 0.57 \\
\hline 131 & 3.44 & 0.44 & 0.59 \\
\hline 132 & 0.17 & 0.07 & 0.10 \\
\hline 133 & 0.17 & 0.08 & 0.10 \\
\hline 134 & 0.19 & 0.09 & 0.11 \\
\hline 135 & 3.63 & 0.53 & 0.71 \\
\hline 136 & 0.52 & 0.02 & 0.00 \\
\hline 137 & 0.55 & 0.02 & 0.01 \\
\hline 138 & 1.07 & 0.04 & 0.01 \\
\hline 139 & 4.72 & 0.59 & 0.74 \\
\hline 140 & 4.73 & 0.60 & 0.75 \\
\hline 141 & 0.24 & 0.02 & 0.01 \\
\hline 142 & 0.24 & 0.02 & 0.02 \\
\hline 143 & 4.98 & 0.62 & 0.77 \\
\hline 144 & 19.64 & 6.40 & 7.74 \\
\hline 145 & 19.64 & 6.40 & 7.74 \\
\hline 146 & 0.25 & 0.01 & 0.01 \\
\hline 147 & 19.90 & 6.41 & 7.74 \\
\hline 148 & 0.41 & 0.04 & 0.01 \\
\hline 149 & 0.41 & 0.04 & 0.01 \\
\hline 150 & 0.99 & 0.62 & 0.64 \\
\hline 151 & 1.24 & 0.87 & 0.89 \\
\hline 152 & 21.14 & 7.28 & 8.64 \\
\hline 153 & 0.40 & 0.02 & 0.00 \\
\hline 154 & 21.54 & 7.30 & 8.62 \\
\hline 155 & 0.65 & 0.65 & 1.30 \\
\hline 156 & 20.89 & 6.66 & 7.32 \\
\hline 157 & 21.47 & 7.24 & 7.90 \\
\hline 158 & 2.21 & 5.65 & 2.72 \\
\hline 159 & 19.26 & 1.59 & 5.18 \\
\hline 160 & 19.26 & 1.59 & 5.18 \\
\hline
\end{tabular}

Velocity values have been obtained applying the formula determined in Appendix IV for every stretch and combining raster layers of water flows, slope and drained area. 
Table 11. Velocity values $(\mathrm{m} / \mathrm{s})$ for every river stretch, on September 22, 2010, September 13, 2011 and the average values in the years 2000-2012 used in the stochastic model.

\begin{tabular}{|c|c|c|c|}
\hline StretchID & Vel. 2010 & Vel. 2011 & Vel. stochastic \\
\hline 1 & 0.35 & 0.32 & 0.40 \\
\hline 2 & 0.33 & 0.32 & 0.50 \\
\hline 3 & 0.53 & 0.37 & 0.35 \\
\hline 4 & 0.50 & 0.40 & 0.30 \\
\hline 5 & 0.50 & 0.50 & 0.53 \\
\hline 6 & 0.55 & 0.65 & 0.70 \\
\hline 7 & 0.70 & 0.58 & 0.55 \\
\hline 8 & 0.65 & 0.60 & 0.60 \\
\hline 9 & 2.00 & 2.00 & 2.00 \\
\hline 10 & 0.70 & 0.70 & 0.55 \\
\hline 11 & 0.45 & 0.40 & 0.45 \\
\hline 12 & 0.47 & 0.35 & 0.28 \\
\hline 13 & 0.32 & 0.23 & 0.20 \\
\hline 14 & 0.55 & 0.80 & 0.70 \\
\hline 15 & 0.50 & 0.75 & 0.60 \\
\hline 16 & 0.42 & 0.52 & 0.50 \\
\hline 17 & 0.45 & 0.30 & 0.45 \\
\hline 18 & 0.40 & 0.26 & 0.36 \\
\hline 19 & 0.55 & 0.90 & 0.78 \\
\hline 20 & 0.60 & 0.70 & 0.70 \\
\hline 21 & 0.60 & 0.35 & 0.40 \\
\hline 22 & 0.65 & 0.45 & 0.55 \\
\hline 23 & 0.73 & 0.88 & 0.75 \\
\hline 24 & 0.70 & 0.88 & 0.75 \\
\hline 25 & 0.45 & 0.15 & 0.43 \\
\hline 26 & 0.42 & 0.16 & 0.40 \\
\hline 27 & 0.80 & 0.80 & 0.70 \\
\hline 28 & 0.57 & 0.90 & 0.80 \\
\hline 29 & 2.00 & 2.00 & 2.00 \\
\hline 30 & 0.50 & 0.50 & 0.65 \\
\hline 31 & 0.35 & 0.23 & 0.30 \\
\hline 32 & 0.35 & 0.20 & 0.25 \\
\hline 33 & 0.45 & 0.22 & 0.23 \\
\hline 34 & 0.25 & 0.18 & 0.20 \\
\hline 35 & 0.33 & 0.19 & 0.19 \\
\hline 36 & 0.42 & 0.26 & 0.30 \\
\hline 37 & 0.24 & 0.12 & 0.18 \\
\hline 38 & 0.25 & 0.17 & 0.19 \\
\hline 39 & 0.30 & 0.21 & 0.23 \\
\hline 40 & 0.53 & 0.30 & 0.32 \\
\hline
\end{tabular}




\begin{tabular}{|c|c|c|c|}
\hline 41 & 0.40 & 0.22 & 0.35 \\
\hline 42 & 0.47 & 0.35 & 0.35 \\
\hline 43 & 0.25 & 0.32 & 0.35 \\
\hline 44 & 0.65 & 0.65 & 0.75 \\
\hline 45 & 0.19 & 0.18 & 0.10 \\
\hline 46 & 0.25 & 0.18 & 0.20 \\
\hline 47 & 0.20 & 0.25 & 0.18 \\
\hline 48 & 0.24 & 0.24 & 0.15 \\
\hline 49 & 0.21 & 0.24 & 0.16 \\
\hline 50 & 0.30 & 0.30 & 0.25 \\
\hline 51 & 0.70 & 0.70 & 0.80 \\
\hline 52 & 0.16 & 0.22 & 0.16 \\
\hline 53 & 0.24 & 0.45 & 0.18 \\
\hline 54 & 0.75 & 0.30 & 0.55 \\
\hline 55 & 0.26 & 0.70 & 0.17 \\
\hline 56 & 0.64 & 0.50 & 0.65 \\
\hline 57 & 0.64 & 0.65 & 0.50 \\
\hline 58 & 0.67 & 0.65 & 0.65 \\
\hline 59 & 0.40 & 0.25 & 0.50 \\
\hline 60 & 0.22 & 0.13 & 0.25 \\
\hline 61 & 0.41 & 0.12 & 0.32 \\
\hline 62 & 0.30 & 0.18 & 0.37 \\
\hline 63 & 0.25 & 0.13 & 0.25 \\
\hline 64 & 0.48 & 0.23 & 0.45 \\
\hline 65 & 0.50 & 0.40 & 0.50 \\
\hline 66 & 0.55 & 0.45 & 0.50 \\
\hline 67 & 0.44 & 0.60 & 0.67 \\
\hline 68 & 0.65 & 0.60 & 0.75 \\
\hline 69 & 0.27 & 0.30 & 0.14 \\
\hline 70 & 0.33 & 0.37 & 0.25 \\
\hline 71 & 0.19 & 0.17 & 0.10 \\
\hline 72 & 0.23 & 0.25 & 0.13 \\
\hline 73 & 0.27 & 0.30 & 0.20 \\
\hline 74 & 0.41 & 0.42 & 0.44 \\
\hline 75 & 0.58 & 0.60 & 0.70 \\
\hline 76 & 0.35 & 0.35 & 0.30 \\
\hline 77 & 0.70 & 0.50 & 0.60 \\
\hline 78 & 2.00 & 2.00 & 2.00 \\
\hline 79 & 0.59 & 0.40 & 0.80 \\
\hline 80 & 0.19 & 0.23 & 0.25 \\
\hline 81 & 0.60 & 0.60 & 0.73 \\
\hline 82 & 0.17 & 0.22 & 0.22 \\
\hline 83 & 0.69 & 0.50 & 0.55 \\
\hline 84 & 0.58 & 0.60 & 0.65 \\
\hline 85 & 0.52 & 0.50 & 0.50 \\
\hline
\end{tabular}




\begin{tabular}{|c|c|c|c|}
\hline 86 & 0.56 & 0.70 & 0.65 \\
\hline 87 & 0.20 & 0.12 & 0.10 \\
\hline 88 & 0.45 & 0.15 & 0.13 \\
\hline 89 & 0.46 & 0.62 & 0.60 \\
\hline 90 & 0.26 & 0.20 & 0.18 \\
\hline 91 & 0.62 & 0.43 & 0.70 \\
\hline 92 & 0.25 & 0.40 & 0.20 \\
\hline 93 & 0.70 & 0.65 & 1.00 \\
\hline 94 & 0.60 & 0.90 & 0.90 \\
\hline 95 & 0.69 & 0.45 & 0.40 \\
\hline 96 & 0.22 & 0.25 & 0.17 \\
\hline 97 & 0.28 & 0.25 & 0.25 \\
\hline 98 & 0.70 & 0.75 & 0.80 \\
\hline 99 & 0.75 & 0.80 & 0.80 \\
\hline 100 & 0.90 & 0.85 & 0.80 \\
\hline 101 & 0.82 & 0.92 & 0.95 \\
\hline 102 & 0.85 & 0.95 & 1.10 \\
\hline 103 & 0.98 & 1.05 & 1.08 \\
\hline 104 & 0.94 & 0.70 & 0.90 \\
\hline 105 & 0.45 & 0.18 & 0.18 \\
\hline 106 & 0.49 & 0.17 & 0.12 \\
\hline 107 & 0.40 & 0.16 & 0.13 \\
\hline 108 & 0.89 & 0.80 & 0.86 \\
\hline 109 & 2.00 & 2.00 & 2.00 \\
\hline 110 & 0.60 & 0.83 & 0.89 \\
\hline 111 & 0.49 & 0.20 & 0.15 \\
\hline 112 & 0.48 & 0.15 & 0.12 \\
\hline 113 & 0.50 & 0.18 & 0.20 \\
\hline 114 & 0.40 & 0.28 & 0.25 \\
\hline 115 & 0.26 & 0.50 & 0.87 \\
\hline 116 & 0.25 & 0.22 & 0.23 \\
\hline 117 & 0.26 & 0.25 & 0.20 \\
\hline 118 & 0.25 & 0.25 & 0.28 \\
\hline 119 & 0.20 & 0.20 & 0.20 \\
\hline 120 & 0.24 & 0.19 & 0.22 \\
\hline 121 & 0.26 & 0.20 & 0.16 \\
\hline 122 & 0.30 & 0.20 & 0.24 \\
\hline 123 & 0.29 & 0.18 & 0.26 \\
\hline 124 & 0.32 & 0.24 & 0.30 \\
\hline 125 & 0.35 & 0.35 & 0.45 \\
\hline 126 & 0.37 & 0.20 & 0.34 \\
\hline 127 & 0.38 & 0.25 & 0.28 \\
\hline 128 & 0.41 & 0.27 & 0.33 \\
\hline 129 & 0.37 & 0.40 & 0.35 \\
\hline 130 & 0.47 & 0.35 & 0.42 \\
\hline
\end{tabular}




\begin{tabular}{|c|c|c|c|}
\hline 131 & 0.49 & 0.33 & 0.40 \\
\hline 132 & 0.30 & 0.25 & 0.30 \\
\hline 133 & 0.37 & 0.28 & 0.32 \\
\hline 134 & 0.30 & 0.25 & 0.28 \\
\hline 135 & 0.49 & 0.50 & 0.50 \\
\hline 136 & 0.45 & 0.25 & 0.12 \\
\hline 137 & 0.51 & 0.22 & 0.16 \\
\hline 138 & 0.47 & 0.25 & 0.15 \\
\hline 139 & 0.60 & 0.35 & 0.35 \\
\hline 140 & 0.56 & 0.40 & 0.38 \\
\hline 141 & 0.30 & 0.20 & 0.17 \\
\hline 142 & 0.42 & 0.23 & 0.19 \\
\hline 143 & 0.50 & 0.40 & 0.40 \\
\hline 144 & 0.80 & 0.65 & 0.70 \\
\hline 145 & 0.78 & 0.70 & 0.74 \\
\hline 146 & 0.38 & 0.20 & 0.17 \\
\hline 147 & 0.60 & 0.65 & 0.65 \\
\hline 148 & 0.36 & 0.18 & 0.10 \\
\hline 149 & 0.33 & 0.22 & 0.15 \\
\hline 150 & 0.39 & 0.33 & 0.42 \\
\hline 151 & 0.27 & 0.32 & 0.27 \\
\hline 152 & 0.55 & 0.50 & 0.45 \\
\hline 153 & 0.43 & 0.22 & 0.05 \\
\hline 154 & 0.70 & 0.40 & 0.50 \\
\hline 155 & 2.00 & 2.00 & 2.00 \\
\hline 156 & 0.70 & 0.40 & 0.59 \\
\hline 157 & 0.52 & 0.50 & 0.55 \\
\hline 158 & 2.00 & 2.00 & 2.00 \\
\hline 159 & 0.47 & 0.20 & 0.32 \\
\hline 160 & 0.30 & 0.15 & 0.20 \\
\hline
\end{tabular}

